\title{
Are banking shocks contagious? Evidence from the eurozone
}

\author{
Mardi Dungey ${ }^{\mathrm{a}}$, Thomas J. Flavin ${ }^{\mathrm{b}, *}$, Dolores Lagoa-Varela ${ }^{\mathrm{c}}$ \\ a University of Tasmania, Australia \\ ${ }^{\mathrm{b}}$ Department of Economics, Finance and Accounting, Maynooth University, Maynooth, County Kildare, Ireland \\ ${ }^{\mathrm{c}}$ Universidad de A Coruña, Spain
}

\section{A R T I C L E I N F O}

\section{Article history:}

Received 21 September 2016

Accepted 23 July 2018

Available online $\mathrm{xxx}$

JEL classification:

G01

G21

C32

Keywords:

Contagion

Shock transmission

Banking crises

\begin{abstract}
A B S T R A C T
We analyze the transmission of shocks between global banking, domestic banking and the non-financial sector for eleven Eurozone countries. Using a Markov-switching Factor augmented VAR model, we distinguish between contagion, interdependence and decoupling as shock transmission mechanisms during the 'crisis' regime. Contagion played a role in propagating global banking shocks to the banking sectors of smaller states, exacerbating the crisis in these countries. In contrast, the non-financial sectors suffered little contagion from either external or domestic banking shocks, and generally managed to decouple from the banking industry - indicative of being able to source alternative financing and shield themselves from the crisis. However, shocks originating in the non-financial sector trigger contagious effects for both the domestic banking sector and, to a lesser extent global banking, thereby acting as a source of fragility for the financial sector during crisis periods.
\end{abstract}

(c) 2018 Elsevier B.V. All rights reserved.

\section{Introduction}

Recently, numerous Eurozone countries have suffered crises in their banking sectors, with these problems contributing to financial and economic downturns in many countries. ${ }^{1}$ We focus on the extent to which banking shocks affected non-financial corporations (NFCs) in Eurozone countries during 2004-2015 and how shocks originating in the NFC sector affected the banking industry. In particular, we analyze the stability of the transmission of banking global and domestic - shocks to the domestic NFC sector between 'normal' and 'crisis' market conditions, while allowing for potential feedback effects. During the crisis, we distinguish between shock transmission that could be anticipated from pre-existing linkages (interdependence) and transmissions that were either more intense (contagion) or dampened (decoupling) relative to the pre-crisis period. We include both transmissions coming from the banking sector in reducing credit availability to the non-financial sector, and the potential that shocks in the non-financial sector can lead to fragility in the banking network as in Acemoglu et al. (2015). The accurate characterization of the transmission mechanism is

\footnotetext{
* Corresponding author.

E-mail addresses: Mardi.Dungey@utas.edu.au (M. Dungey), thomas.flavin@mu.ie (T.J. Flavin), dlagoa@udc.es (D. Lagoa-Varela).

1 Laeven and Valencia (2013a) present estimates of the financial and output costs of the banking crisis over the period 2008-11 (Table A1, pp. 254-59). There is great variation across Eurozone countries, with Greece, Ireland, Italy, Portugal and Spain all suffering badly.
}

a critical issue for both investors and policy makers. It will impact the effectiveness of investors' diversification strategies, while policy makers must design appropriate responses to alleviate the spread of banking distress to the non-financial sector and to overcome the 'robust-but-fragile' elements of banking networks which make them vulnerable to amplified transmission in response to unusually large or unusually coincidental shocks from the nonfinancial sector. The appropriate policy responses will depend on the sources and propagation mechanism of the shocks.

We develop a Markov-switching factor-augmented vector autoregression (MS-FAVAR) model to incorporate the possibility of shock transmission to domestic non-financial firms from either the domestic banking sector or turmoil in global banking, and to allow feedback effects where NFC shocks may impact on the banking sector. The model allows us to assess the stability of shock transmission across low- and high- volatility regimes and to distinguish between three possible types of transmission. Contagion represents an increase in intensity of shock transmission during periods of high volatility (Forbes and Rigobon, 2002). Decoupling represents the case when shock transmission becomes less intense during periods of stress (Korinek et al., 2010). Finally, interdependence is when the usually observed linkages between the sectors 
are unchanged between calm and crisis periods, after accounting for the fact that correlations change with volatility conditions. ${ }^{2}$

Our study is motivated by three strands of literature; namely the effects of banking crises on the real economy, the effects of real economy events on the banking sector, and contagion in financial markets. The seminal work of Bernanke (1983) shows that banking crashes may accentuate downturns in the real economy and lead to, or prolong, economic recessions. ${ }^{3}$ Economic downturns are, in turn, likely to affect NFCs and their stock prices. Tong and Wei (2009) identify two channels - finance and demand - through which a banking crisis can spread to NFCs; the finance channel refers to external funding problems, while the demand channel arises due to lower consumption in a recession. The finance channel is predominantly associated with credit flow disturbances during a banking crisis. These have been shown to have real economic effects (e.g. Bernanke and Gertler, 1985) with credit restrictions adversely affecting NFCs that are unable to substitute bank loans for other forms of external financing (Peek et al., 2003 and Laeven and Valencia, 2013b, among others). However, Adrian et al. (2012) find that during the recent crisis, U.S. firms could source direct debt funding on the bond market to compensate for the reduction in intermediated bank loans: the adverse effects of the crisis were driven by a general jump in risk premiums rather than bank loan restrictions.

Unanticipated shocks to real economy firms can directly affect the banking sector which provides them with credit services by reducing bank balance sheet assets to an extent which impairs their ability to service their liabilities. The network of relationships between banks, either domestic or global, may be sufficient to compensate for these shocks most of the time, that is it is robust. However, Acemoglu et al. (2015) show that when real economy firm shocks are large enough, or coincidental enough, they can be sufficient to trigger a cascade of failures across the banking sector, resulting in an overall banking network which is 'robustbut-fragile'. For this reason, our modeling framework specifically incorporates the potential for shocks to flow not only from banking to the real economy but also from the real economy firms to banks. As we deal with publicly-listed firms in our empirical application it is reasonable to assume that the NFCs are relatively large, and may reasonably be held not only by the domestic banks in their jurisdiction but also directly by global banks, as well as indirectly through the exposure of global banks to the relevant domestic banks.

Our third contribution is in the detection of financial market contagion or shock transmission associated with a banking crisis. Due to the highly integrated nature of the international banking industry, (see Bekaert et al., 2009), the existing literature focuses on the international transmission of banking shocks. Contagion is a debated term, but we adopt the convention here that it distinguishes between 'normal' levels of asset interdependence and those that are excessive or unpredictable during a crisis period (see Forbes and Rigobon, 2002; Bekaert et al., 2014; Caporin et al., 2018). There is substantial evidence for the existence of widespread contagion across international banking markets following the US banking crisis of 2008 (see Dungey and Gajurel, 2015; Fry-McKibbin and Hsaio, 2015; Gropp et al., 2009). Despite evidence of contagion between international banks, relatively little attention has been afforded to the propagation of bank-

\footnotetext{
2 Failure to account for these changes may mask interdependence, resulting in the over-detection of either contagion or decoupling, a point made by a substantive literature beginning with Forbes and Rigobon (2002).

${ }^{3}$ A voluminous literature exists on the relationship between banking crises and economic growth. We do not attempt to review this literature here but the reader is referred to Reinhart and Rogoff (2009) and Dwyer et al. (2013) for reviews and alternative views.
}

ing shocks to other sectors of the stock market. ${ }^{4}$ Exceptions are Bekaert et al. (2014) and Dungey and Renault (2018). The former tests for contagion from a U.S. factor, a global financial factor and a domestic factor to a range of country and industry portfolios. They find widespread evidence of contagion, with the domestic factor outweighing the other factors as the main source of contagion for many regions and industries. The latter analyze the transmission of banking shocks to a number of selected sectoral indices within the U.S. and find mixed evidence of contagion.

Contagion can accelerate and worsen the economic implications of a crisis period, for example via the so-called 'diabolical loop' of Brunnemeier et al. (2016) where falling equity prices can lead to bank recapitalization programs funded by sovereign debt, which in turn reduces the expected future value of the sovereign debt. Other mechanisms to affect the real economy include asset fire sales, a reduction in lending due to higher capital requirements and increasing risk premia in interbank markets. These factors reinforce each other and precipitate a negative downward spiral in the value of banks.

Using the MS-FAVAR model for eleven Eurozone countries we show that shock transmission is often unstable across low- and high-volatility regimes but patterns of contagion, interdependence and decoupling vary by the pair of markets analyzed. As in the existing literature we find that calm and crisis regimes are persistent and well-identified (see Bialkowski and Serwa, 2005). The crisis and non-crisis regime-specific generalized impulse response functions (GIRFs) suggest that, for many countries, there is a more intensive shock transmission during a crisis (contagion) from the global banking factor to the domestic banking sector, especially for smaller countries. However, decoupling is also observed for a small number of countries, implying that some domestic banks could partially offset the global shock and thus fared better than anticipated.

The transmission of shocks originating in domestic banks to the global banking sector is largely unaltered between non-crisis and crisis periods. In this sense the banking sector is robust to the shocks generated within individual country sectors, but the domestic banking sectors are more fragile to shocks originated in the global banking sector.

The NFC sector does not seem to suffer contagion from either the global or domestic banking sector during periods of stress. In most cases the evidence suggests that NFCs actually decouple, that is their exposure to banking shocks is reduced in the crisis period compared with the non-crisis period. This could imply that our firms are able to access alternative sources of credit during these periods. Thus, NFCs provided a shield to the real economy from the full force of the banking shock and a partial hedge to equity investors whose portfolios were mainly domestically held; see also Dungey et al. (2018) for the US. The NFCs are, as hypothesised by Acemoglu et al. (2015), a statistically discernible source of shocks that promote contagion to both the domestic and global banking network during periods of crisis.

The paper is structured as follows. Section 2 presents some theoretical foundations for contagion and decoupling and outlines our testable hypothesis. Section 3 describes the econometric methodology and how contagion / decoupling is detected in this framework. Section 4 describes the data and presents summary statistics. Our empirical results are discussed in Section 5, with robustness checks reported in Section 6. Finally, Section 7 contains our conclusions and a discussion of how our results may influence regulation and policy.

\footnotetext{
${ }^{4}$ Grammatikos and Vermeulen (2012) look at the crisis transmission from U.S. to European financials and U.S. to European non-financials. However, they do not look at the cross-sectoral effects.
} 


\section{Theoretical foundations and empirical implementation}

Financial market contagion is often defined as an unanticipated disruption to cross-market relationships during a financial crisis and it usually intensifies the spread of a negative shock from its source to other connected markets, (see Forbes and Rigobon, 2002; Dungey et al., 2005; Gravelle et al., 2006; and Flavin and Sheenan, 2015 among others). The extant literature on financial networks provides a theoretical underpinning for this definition of contagion. Kiyotaki and Moore (1997) show how credit-constrained firms may be forced to sell assets to unconstrained firms, resulting in falling asset prices. Asset price declines further impinge on their ability to access credit markets, creating a strong link between credit restrictions and asset prices. This transmission mechanism has the potential to generate negative consequences for the non-financial sector, especially firms that are dependent on external financing. More recently, Acemoglu et al. (2015) shows how instability may arise where counterparty risk in a highly-integrated network, like the global banking system, can cause different behavior beyond some threshold level of either the number or magnitude of shocks. Properties of the network that act as shock absorbers in 'normal' times, can actually make the system vulnerable to contagion and systemic risk in 'crisis' periods, resulting in a 'robust-but-fragile' network. Other theoretical contributions use different triggers but also demonstrate how contagion may result due to the inter-connectedness of the banking industry (see Allen and Gale, 2000; Allen et al., 2012; and Elliot et al., 2014 among others).

Korinek et al. (2010) illustrate how contagion and decoupling may occur during a crisis. In their model, there are three sectors; two NFCs and one financial. The initial shock occurs in a nonbanking sector and the bank acts as a transmitter of the shock. If the shock is below a threshold, the bank suffers some losses and stops credit to the affected sector but continues to supply credit to the other. This causes the two NFC sectors to decouple. However, if the shock is above the threshold, the bank may become sufficiently impaired as to restrict credit to both NFCs, thus resulting in contagion between these sectors. This idea can be generalized to shocks that originate in global and domestic banks and potentially alters their relationship with NFCs.

Since theoretical models imply that contagion / decoupling result in multiple equilibria, regime-switching models provide an ideal empirical framework within which to analyse the stability of the propagation of shocks from a source market to related markets.

Our framework fits within the literature on crises and contagion measurement that tests for changes in the transmission mechanisms between assets during periods of calm and stress. In this approach the framework is to test whether the propagation of shocks between assets remains the same in periods of high volatility (stress) as in low volatility (calm). An alternative approach is to distinguish the transmission effect in observations in the tail of the distributions from those within other parts of the distribution, essentially implying a non-linearity in the transmission of information based on the size of the information shock. Examples include the quantile regression approach of Caporin et al. (2018); comparisons of copulas in Busetti and Harvey (2011); co-exceedances in Bae et al. (2003); and outliers in Favero and Giavazzi (2002). The MS approach implemented here applies to the change in transmission across the distribution of returns, but allows for relatively short crisis periods, capturing some degree of non-linearity. This is a major advantage of this alternative approach.

A key decision in detecting contagion is in distinguishing the non-crisis and crisis periods, for which three main methods exist. The most common is the use of event based criteria, such as the collapse of a market or a market intervention, though it may be difficult to find a consensus on the exact start and end dates. For example, Dungey et al. (2015) document 22 published identifications of the global financial crisis sample. An alternative is to use a two-step process to identify subsamples via structural break tests or tests for outliers. Using different methods, this approach is adopted by Contessi et al. (2014), Dungey and Gajurel (2015), Kallberg et al. (2005), Boyson et al. (2010), and Pasquariello (2008). Finally, a few papers endeavour to, simultaneously, identify the sample regimes and test for contagion. Blatt et al. (2015) propose an ingenious iterative procedure, based on a VAR, which iterates through structural break points to obtain the best fit of regimes and breaks. Most of the other papers, in this category, use a regime-switching framework. For example, Dungey et al. (2015) use a smooth transition VAR but find that in practice the transition is very abrupt, while MS models based on volatility regimes are employed in Jeanne and Masson (2000), Gravelle et al. (2006), Flavin and Panopoulou (2009), Flavin and Sheenan (2015) and Konermann et al. (2017). Our paper fits in this final group.

When searching for contagion and crisis effects switching models usually differentiate between two main volatility states: low (representing calm markets) and high (representing stress). That is, the switching variable is based on a form of volatility measure. ${ }^{5} \mathrm{~A}$ small number of studies allow the mean and variance processes to independently change regimes, e.g. Bialkowski and Serwa (2005), Bialkowski et al. (2006), and Blatt et al. (2015). If the mean and variance regimes switch at different times, then using the notation $+/$ - for the mean states and $\mathrm{L}(\mathrm{H})$ for the low(high) volatility state, we can consider four possible states:

I. Positive mean returns and low risk $(+, \mathrm{L})$;

II. Negative mean returns and high risk $(-, \mathrm{H})$;

III. Negative mean returns and low risk $(-, \mathrm{L})$; and

IV. Positive mean returns and high risk $(+, \mathrm{H})$.

In studies of equity returns, scenarios I and II are most often found to characterise stock return behavior during 'normal' and 'crisis' conditions. Scenarios III and IV are expected to be relatively short-lived. ${ }^{6}$ This hypothesis is confirmed, in the Markovswitching literature, by Bialkowski and Serwa (2005) who estimate fully flexible mean- and volatility-switching regimes, and find that the equivalent of regimes I and II are very persistent in the Asian crisis (whereas III and IV are fleeting); see also Bialkowski et al. (2006) for additional European evidence. An implementation of this outcome can be found in Konermann et al. (2017) who specifies one mean return for all high volatility periods and one for all calm periods, that is case I and III are combined as are case II and IV. We also follow this approach.

With two volatility regimes, which we label as 'normal' and 'crisis', we compare the responses of the recipient market to a particular shock across these regimes. The transmission of a shock during 'normal' market conditions captures their interdependence and represents their 'normal' linkages. If this transmission is stable (i.e. not statistically significantly different) between regimes, then we conclude that the market co-movements during the crisis period are driven by market interdependence and the propagation of the shock could have been anticipated from the relation-

\footnotetext{
5 Switching between the regimes may also be based on variables such as time, the VIX or occurrence of jumps as in Dungey et al. (2015) and Konermann et al. (2017). We undertook robustness to this approach and find that the switching times we identify are basically unchanged. We also find that the lagged US return is a statistically insignificant transition variable while time is statistically significant but economically insignificant. Consequently, we remain with the constant coefficient regime shift model described here. Details are available on request.

${ }^{6}$ This may change for different asset classes. For example, assets who act as safe havens during a crisis would be expected to have much more risk / return realizations in state IV.
} 
ship during 'normal' market conditions. Contagion is defined as the intensification of this transmission mechanism during a crisis period, i.e. where the shock generates a stronger response in the recipient market than that predicted by 'normal' levels of interdependence. ${ }^{7}$ On the other hand, if the transmission is dampened in the crisis regime (the response is statistically significantly lower than expected given market interdependence), this is decoupling. ${ }^{8}$ Hence, our empirical tests focus on the change in the response of one market following a shock to another during the high-volatility regime relative to the low-volatility regime. Our hypothesis can be summarised as follows:

$\mathrm{H}_{\mathrm{o}}$ : No statistical difference in the response across regimes, i.e. interdependence;

$\mathrm{H}_{1 \mathrm{a}}$ : The response intensifies in the high-volatility regime, i.e. contagion;

$\mathrm{H}_{1 \mathrm{~b}}$ : The response is lower in the high-volatility regime, i.e. decoupling.

\section{Econometric methodology}

We adopt a Markov-switching factor-augmented vector autoregression (MS-FAVAR) model to conduct our analysis. The FAVAR model was first introduced by Bernanke et al. (2005) to overcome problems of dimensionality encountered in empirical models of monetary policy and has more recently been applied to issues of spillover and contagion in financial markets by de Bandt and Malik (2010) and Claeys and Vasicek (2014). In our application, the factor is extracted from a broad range of shocks to international banking stock indices and is used as a proxy for global conditions. This model is well suited to addressing our question as it allows us to parsimoniously distinguish between the potential sources of instability arising from external and internal banking conditions.

We incorporate the FAVAR within a Markov-switching approach and generate regime-dependent GIRFs (see Ehrmann et al., 2003) to study the stability of the shock transmission between regimes. First, we extract the common shock. Second, we examine the evidence for contagion between the common shock, the remaining domestic banking shock and the non-financial company shocks for each country using standard correlation based contagion tests. Finally, we implement an MS-FAVAR specification that allows classification of non-contiguous time periods into calm and crisis states, and use this to generate GIRFs which detect contagion / decoupling by comparing the changing dynamics of shock propagation across different regimes. We discuss each stage in greater detail below.

\subsection{Extracting the common factor}

To detect contagion between the banking and the domestic non-financial sectors, we must first properly disentangle external and domestic banking shocks. Given the turmoil across the international banking sector during the period, this is crucial so as not to overestimate the spillover to the non-financial sector from the domestic banking sector. Ideally, we would include all the relevant external shocks but the dimensionality of the model will not allow this, so to overcome this problem we use a common factor to proxy for global conditions. In our analysis of country $i$, we extract a common shock from the banking returns of the other ten Eurozone countries plus the UK and the US. The US and the UK

\footnotetext{
${ }^{7}$ Usually the literature defines contagion as having immediate or contemporaneous effects. For example, Kaminsky et al. (2003) distinguish between 'fast and furious' contagion and more gradual 'spillovers'.

${ }^{8}$ Some studies (e.g. Dungey and Gajurel, 2015) do not differentiate between more and less intense responses in the recipient market, but label all statistically significant deviations from 'interdependence' as contagion.
}

are included as they both suffered major shocks to their banking industries and contributed significantly to the widespread turmoil experienced by the sector. To capture the shock component of the returns, we first run a standard VAR model of the returns and retrieve the vector of residuals. We then perform a principal components based factor analysis of the correlation matrix of residuals and use the first principal component as our common external shock.

\subsection{Correlation based tests}

The existing literature often checks for contagion, via various forms of correlation coefficients, under the null of interdependence, i.e. there is no change in the propagation of a shock from one asset to another during periods of calm and crisis. To illustrate, consider the relationship between two (zero-mean) characteristics (mean or variance) denoted as $x$ and $y$ over different states of the financial market, $t_{1}$ and $t_{2}$.

$y_{t 1}=\beta_{1} x_{t 1}+\varepsilon_{t 1}$

$y_{t 2}=\beta_{2} x_{t 2}+\varepsilon_{t 2}$

The test for no contagion is given by $H_{0}: \beta_{1}=\beta_{2}$. An intuitively appealing form of this test is via correlation coefficients recognizing that $\beta_{i}=\rho_{i} \sigma_{y i} \sigma_{x i}^{-1}$ where $\sigma_{y i}$ and $\sigma_{x i}(i=1,2)$ are the variances of the two assets under consideration. Forbes and Rigobon (2002) show that a test based on $H_{0}: \rho_{1}=\rho_{2}$ is unreliable when asset volatilities change between periods $t_{1}$ and $t_{2}$ except under very special circumstances (which are unlikely to be met). To overcome this they propose a correction based on scaling $\rho_{2}$ by the relative change in volatility. This corrected test dramatically decreases the incidence of contagion evident in the data in both their paper and many subsequent applications. However, subsequent papers have shown that the Forbes and Rigobon (FR) correction is over zealous, and results in over-acceptance of the null of no contagion, (see Corsetti et al., 2005). Dungey et al. (2005) propose a regression based approach (DFGM) to implement the FR correction with improved statistical properties, in which the data for $t_{2}$ are directly scaled by the change in volatility, making it possible to estimate $\beta_{2}$ after controlling for this distortion. ${ }^{9}$ Each of these methods, however, implicitly relies on the assumption that the relative volatility of the asset shocks, $\sigma_{y i} \sigma_{x i}^{-1}$, remains constant across states.

Instead, Dungey and Renault (2018) demonstrates that the propagation parameter is more correctly specified as a combination of a constant propagation and the effect of the changing relative volatilities as follows:

$\beta_{i}=\alpha b_{i}+(1-\alpha) \sigma_{y i} \sigma_{x i}^{-1}$

where $b_{i}$ is the true parameter of interest in assessing changes in propagation, and $\alpha$ is a scaling parameter which turns out to be innocuous in testing. Taking into account the potential change in relative asset volatilities, Dungey and Renault (2018) demonstrate that there may be substantial changes to the detection of the presence of contagion, and that there is no clear indication a priori of the direction or extent of under- or over-detection.

As a benchmark for our results, we implement each of the uncorrected Forbes and Rigobon (FRN) and corrected Forbes and Rigobon (FRC) correlation tests, the DFGM regression test and the DR test for the detection of contagion for our three components (global banking, domestic banking and NFCs). One problem which

\footnotetext{
${ }^{9}$ The Forbes Rigobon (FR) test relies on a Fisher-corrected standard error whereas the DFGM method has statistical significance directly from the regression.
} 
these tests are not specifically designed for is to test using noncontinguous data, where markets may move in and out of crisis and calm states across the sample. In our application, we filter data into each of the two sample periods, as described in the results section.

\subsection{Estimating the MS-FAVAR}

We estimate a three-variable VAR model in a Markov-switching framework for each country. For country $i$, we include the external banking shock (described above) and shocks to the returns of the domestic banking and non-financial sectors. We specify the dependent vector of variables for country $i$ as $;^{10}$

$y_{i, t}=\left\{\text { global factor, bank shock }_{\mathrm{i}} \text {, NFC } \text { shock }_{\mathrm{i}}\right\}_{\mathrm{t}}$.

The shocks to the domestic returns are proxied by the residuals from a first order VAR model with exogenous variables included to capture global stock market and liquidity conditions. For country $i$, the model can be written as:

$r_{j, t}=\alpha_{j}+\rho r_{j, t-1}+\sum_{k=0}^{1} \beta_{j k} r_{w, t-k}+\sum_{k=0}^{1} \gamma_{j k} \Delta T E D_{t-k}+\xi_{j, t}$

where $r_{j}$ (j=banks, non-financials), $r_{w}$ and $\triangle T E D$ represent the sectoral returns, the market portfolio returns and the change in liquidity respectively. ${ }^{11}$

We then proceed to estimate the following MS-FAVAR model:

$y_{i, t}=\lambda\left(s_{t}\right)+\sum_{1}^{p} \theta_{p}\left(s_{t}\right) y_{i, t-p}+\varepsilon_{i, t}^{s t}$

$S_{t} \in\{1,2\}$

$\varepsilon_{i, t}^{s t} \sim$ i.i.d. $\left(0, \sigma_{s}^{2}\right)$

where $y_{i, t}$ is the $3 \times 1$ vector defined above. The regression constant $(\lambda)$, the matrix of autoregressive coefficients $(\theta)$ and the covariance matrix of residuals $(\sigma)$ are all regime-dependent. $S_{t}$ is the unobservable latent variable governing the regime path, which takes a value of unity in 'normal' market conditions (low asset volatility) and a value of 2 in 'crisis' (high-volatility) episodes. Following the regime-switching literature, the regime paths are Markov switching and are endogenously determined. The conditional probabilities of remaining in the same state are defined as follows ${ }^{12}$ :

$\operatorname{Pr}\left[S_{t}=1 \mid S_{t-1}=1\right]=p_{11}$

$\operatorname{Pr}\left[S_{t}=2 \mid S_{t-1}=2\right]=p_{22}$

The model is estimated using a Bayesian Markov-chain Monte Carlo (MCMC) approach. We first specify the prior distributions for the parameters. For the variances, we employ a Wishart distribution, the VAR coefficients have a flat prior and we use a weak Dirichlet prior for the transitions, with a preference towards remaining in the same state. Using Gibbs sampling, we estimate the parameters and regimes in the following sequence;

Step 1: We draw the sigmas, given the mean coefficients and regimes.

\footnotetext{
10 Since we analyze the GIRFs, the ordering of the variables does not matter in specification of the VAR.

11 The TED spread is the difference between the interest rate on interbank loans and short-term U.S. Treasury bills. It is an often-used proxy for market liquidity.

12 We also investigated the possibility of estimating a time-varying transition probability model (TVP) using US lagged bank returns and time as the information variables. However, there was little difference between their estimated probabilities and those from the fixed transition model (FTP) (correlations between the estimated probabilities were always greater than 0.93 and often as large as 0.99 ) so we choose to work with the FTP specification.
}

Table 1

Summary statistics.

\begin{tabular}{|c|c|c|c|c|}
\hline & Mean & Std. Dev & Skewness & Kurtosis \\
\hline \multicolumn{5}{|c|}{ Panel A: Banking stock returns } \\
\hline Austria & 0.0041 & 2.2638 & -0.185 & 5.2985 \\
\hline Belgium & -0.0035 & 2.6652 & -0.4309 & 9.7803 \\
\hline Finland & 0.0566 & 2.136 & 0.1575 & 10.4334 \\
\hline France & 0.0114 & 2.2865 & 0.3087 & 7.6767 \\
\hline Germany & -0.0113 & 2.0258 & -0.0379 & 11.2752 \\
\hline Greece & -0.1378 & 3.3755 & 0.0060 & 7.6254 \\
\hline Ireland & -0.0842 & 4.3709 & -1.45 & 37.572 \\
\hline Italy & -0.002 & 2.1109 & -0.1161 & 4.7339 \\
\hline Netherlands & -0.0393 & 2.2532 & -4.7409 & 99.1813 \\
\hline Portugal & -0.0535 & 2.1532 & 0.0944 & 6.1827 \\
\hline Spain & 0.0178 & 1.9542 & 0.4462 & 9.8685 \\
\hline UK & -0.0094 & 1.9341 & -0.1112 & 15.3589 \\
\hline US & -0.0019 & 2.3739 & 0.1347 & 17.3561 \\
\hline \multicolumn{5}{|c|}{ Panel B: Non-financial stock returns } \\
\hline Austria & 0.0337 & 1.2316 & -0.4276 & 6.6764 \\
\hline Belgium & 0.0594 & 1.0535 & -0.3320 & 4.4304 \\
\hline Finland & 0.0227 & 1.4779 & -0.1834 & 4.8460 \\
\hline France & 0.033 & 1.1673 & 0.0347 & 8.2581 \\
\hline Germany & 0.0402 & 1.2022 & 1.0284 & 28.9875 \\
\hline Greece & 0.0053 & 1.5269 & -0.2143 & 5.0090 \\
\hline Ireland & 0.0402 & 1.2869 & -0.7909 & 6.8867 \\
\hline Italy & 0.0239 & 1.2408 & -0.1187 & 7.1506 \\
\hline Netherlands & 0.0346 & 1.1815 & -0.4429 & 8.5255 \\
\hline Portugal & 0.0237 & 1.133 & -0.21681 & 10.0376 \\
\hline Spain & 0.0378 & 1.1831 & -0.1031 & 5.8661 \\
\hline
\end{tabular}

Notes: This Table presents summary statistics for all the sectoral returns used in the study.

Step 2: We draw the mean coefficients ( $\boldsymbol{\lambda}$ and $\boldsymbol{\theta}$ ) given sigmas and regimes.

Step 3: We draw the regimes, given the sigmas and mean coefficients.

Step 4: We draw the transition parameters.

This sequence of steps is repeated 10,000 times after discarding an initial 'burn-in' set of 2,000 replications. Once we have obtained our estimated parameters, we generate the regimedependent GIRFs and their associated confidence bands. We interpret a statistically significant increase in the response of variable $j$ to a shock to variable $i$ in the crisis regime as contagion from $i$ to $j$. On the other hand, a statistically significant decrease constitutes decoupling. If the IRF is unchanged between regimes, this is interdependence.

\section{Data}

Our data consists of daily stock returns for the banking and NFC sectors of eleven Eurozone countries plus the UK and the US. The UK and the US are included to give broad coverage of external (or non-Eurozone) events that potentially exerted common shocks throughout the global banking system. All data are Datastreamconstructed indices to represent the sectors under investigation. The mnemonics have the form BANKS + CC (for the banking sector) and TOTLI + CC (for the non-financial sector) where CC represents the country-specific suffix. The full set of countries analyzed are Austria, Belgium, Finland, France, Germany, Greece, Ireland, Italy, the Netherlands, Portugal, Spain, the UK and the US. When identifying domestic shocks, we proxy for developments in global stock markets and funding / liquidity markets by including a Datastream-constructed world market portfolio (TOTMKWD) and the TED spread respectively. The latter is obtained from the database of the Federal Reserve Board. Our sample begins on January 1, 2004 and runs until March 31, 2015. The starting point is chosen to avoid contamination with earlier crises such as the bursting of the Dot.com bubble or the collapse of the LTCM hedge 
Table 2

Details of model and regimes.

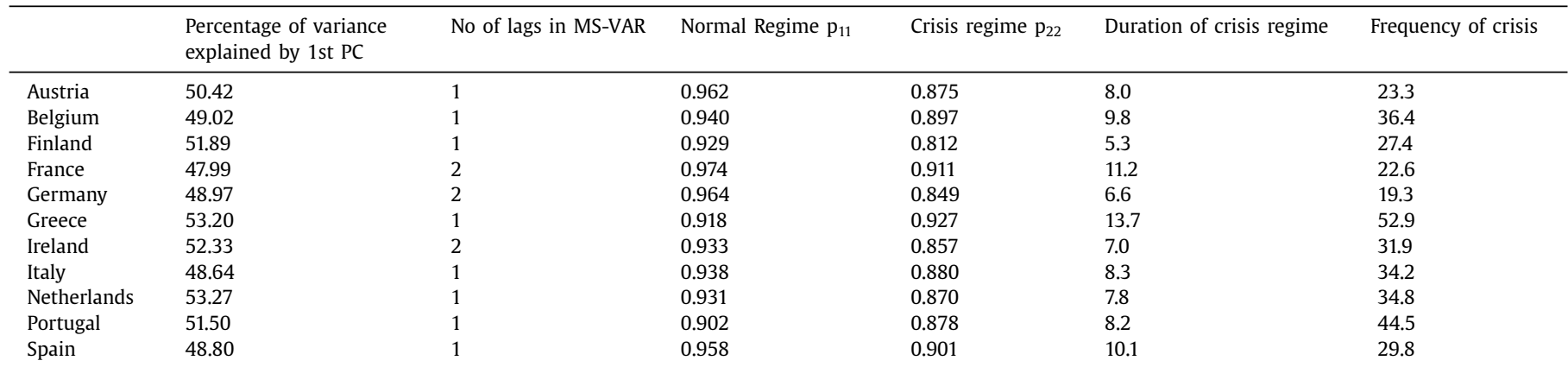

Notes: We present information on our model specification and the frequency and persistence of regimes. Column 2 reports the proportion of the variance of banking stocks in the UK and the US plus the other ' $n-1$ ' Eurozone countries that is explained by our global factor. Column 3 tells us the number of lags included in the MS-FAVAR model Columns 4 and 5 present the probabilities of remaining in the 'normal' $\left(\mathrm{p}_{11}\right)$ and 'crisis' $\left(\mathrm{p}_{22}\right)$ regimes respectively, given that you began the period in that regime. The probability of moving to the other state is $1-\mathrm{p}_{\mathrm{ii}}$. Columns 6 and 7 presents statistics about the regimes. Frequency measures the proportion of time that each country spends in the 'crisis' regime, while Duration measures the length of time (in days) for which the shock persists. Frequency and Duration are calculated as $\left(1-\mathrm{p}_{11}\right) /\left(2-\mathrm{p}_{11}-\mathrm{p}_{22}\right)$ and $1 /(1-\mathrm{p} 22)$ respectively with $\mathrm{p}_{11}$ and $\mathrm{p}_{22}$ as defined in Eq. (3).

Table 3

Regime-specific correlations.

\begin{tabular}{|c|c|c|c|c|c|c|}
\hline & \multicolumn{2}{|c|}{ Global bank factor \& domestic banks } & \multicolumn{2}{|c|}{ Global bank factor \& domestic NFCs } & \multicolumn{2}{|c|}{ Domestic banks \& domestic NFCs } \\
\hline & Normal & Crisis & Normal & Crisis & Normal & Crisis \\
\hline Austria & 0.506 & 0.505 & 0.359 & 0.399 & 0.451 & 0.546 \\
\hline Belgium & 0.482 & 0.559 & 0.354 & 0.313 & 0.402 & 0.293 \\
\hline Finland & 0.356 & 0.450 & 0.364 & 0.299 & 0.391 & 0.383 \\
\hline France & 0.659 & 0.610 & 0.494 & 0.380 & 0.631 & 0.524 \\
\hline Germany & 0.519 & 0.536 & 0.442 & 0.202 & 0.558 & 0.247 \\
\hline Greece & 0.199 & 0.228 & 0.172 & 0.240 & 0.653 & 0.616 \\
\hline Ireland & 0.392 & 0.342 & 0.335 & 0.332 & 0.402 & 0.242 \\
\hline Italy & 0.548 & 0.568 & 0.463 & 0.446 & 0.630 & 0.658 \\
\hline Netherlands & 0.348 & 0.142 & 0.394 & 0.428 & 0.428 & 0.171 \\
\hline Portugal & 0.319 & 0.415 & 0.217 & 0.411 & 0.474 & 0.467 \\
\hline Spain & 0.602 & 0.523 & 0.524 & 0.451 & 0.764 & 0.722 \\
\hline
\end{tabular}

Notes: This presents the regime-dependent pairwise correlations generated by our MS-FAVAR model.

fund. Table 1 presents summary statistics for the variables employed in the analysis.

Panels A and B of Table 1 refer to banking sector and NFC stock returns respectively. There are striking differences between the bank returns and those on the non-financial sectors. The mean return on NFCs is positive in every country, while returns to banking stocks are, on average, negative for nine of the thirteen countries in our sample. Finland records the highest average daily return while Irish and Greek banks have the largest negative returns. In fact, Finland is the only country whose banking stocks record a higher mean return than their NFC counterparts over the period. Banking stocks are also more risky, with a higher standard deviation compared to the NFCs in every country. Among the Eurozone countries, particularly high levels of risk are observed in states where banks had to be bailed out by domestic governments such as Ireland, Belgium, the Netherlands and Greece. Spain is an exception since it was predominantly a large number of small banks that required state support, while the larger banks performed relatively well. Non-financial firms in Belgium performed particularly well over the sample, recording the highest average return and the lowest standard deviation of return. Greek NFCs have the smallest mean and largest risk measure. Furthermore, all returns (for both sectors) exhibit skewness and strong evidence of kurtosis. The prevalence of fat tails suggests that modeling these returns in a Markov-switching framework may be better than in a single state setting.

To aid in the explanation of our results, we source data on bank sector credit (Table F2_4) and total credit (Table F2_2) to the private non-financial sector for all countries from the Bank of Interna- tional Settlements (BIS). We also use the BIS consolidated banking statistics (Table b4) to construct a regional breakdown of the foreign claims of the banking sector in each of our countries. Claims are computed on an ultimate risk basis.

\section{Discussion of results}

\subsection{Results of the MS-FAVAR model}

Table 2 presents an overview of the MS-FAVAR model specification and some statistics for the identified regimes in each country.

Firstly, the global or common banking factor extracted in the principal components analysis represents about $50 \%$ of the total variation in banking stocks across the sector. It varies from a low of $48 \%$ in the model for France to a high of $53 \%$ in the specifications for Greece and the Netherlands. ${ }^{13}$ Initially, the number of lags included in the country-specific MS-FAVAR is selected using the Hannan-Quinn information criterion. After estimation, we check for residual autocorrelation in the expected residuals and where this is found, we proceed to add lags to the VAR until the final lag is no longer statistically significant in any of the estimated equations.

We report the 'Frequency' and 'Duration' statistics for the highvolatility regime in Table 2 . The transition probabilities for each of the countries support the hypothesis that generally the models have high probability of remaining in either the crisis or calm

\footnotetext{
13 The global factor is highly correlated across countries. The first eigenvalue ex plains about $99 \%$ of the cross-sectional variation. Therefore, the global factor is essentially the same in each country analysis.
} 
Table 4

Correlation-based tests of contagion.

\begin{tabular}{|c|c|c|c|c|c|c|c|c|c|c|c|c|}
\hline & \multicolumn{4}{|c|}{ Global to domestic banks } & \multicolumn{4}{|c|}{ Domestic banks to global } & \multicolumn{4}{|c|}{ NFC to global } \\
\hline & $\mathrm{FR}^{\mathrm{N}}$ & $\mathrm{FR}^{\mathrm{C}}$ & DFGM & $\overline{\mathrm{DR}}$ & $\mathrm{FR}^{\mathrm{N}}$ & $\mathrm{FR}^{\mathrm{C}}$ & DFGM & $\overline{\mathrm{DR}}$ & $\overline{\mathrm{FR}^{\mathrm{N}}}$ & $\mathrm{FR}^{\mathrm{C}}$ & DFGM & $\overline{\mathrm{DR}}$ \\
\hline Austria & I & $\mathrm{C}$ & I & $\mathrm{D}$ & I & D & $\mathrm{C}$ & I & I & $\mathrm{D}$ & $\mathrm{C}$ & I \\
\hline Belgium & $\mathrm{C}$ & $\mathrm{D}$ & $\mathrm{C}$ & I & C & D & $\mathrm{C}$ & I & I & $\mathrm{D}$ & $\mathrm{C}$ & I \\
\hline Finland & $\mathrm{C}$ & $\mathrm{D}$ & $\mathrm{C}$ & $\mathrm{D}$ & C & $\mathrm{D}$ & $\mathrm{C}$ & I & I & $\mathrm{D}$ & I & I \\
\hline France & $\mathrm{D}$ & $\mathrm{D}$ & $\mathrm{C}$ & $\mathrm{D}$ & $\mathrm{D}$ & $\mathrm{D}$ & $\mathrm{C}$ & I & $\mathrm{D}$ & $\mathrm{D}$ & $\mathrm{D}$ & I \\
\hline Germany & I & $\mathrm{D}$ & I & $\mathrm{D}$ & I & $\mathrm{D}$ & $\mathrm{C}$ & I & $\mathrm{D}$ & $\mathrm{D}$ & I & I \\
\hline Greece & I & $\mathrm{D}$ & $\mathrm{C}$ & $\mathrm{C}$ & I & D & $\mathrm{C}$ & I & $\mathrm{C}$ & $\mathrm{D}$ & I & I \\
\hline Ireland & I & $\mathrm{D}$ & $\mathrm{C}$ & I & I & $\mathrm{D}$ & I & I & $\mathrm{I}$ & $\mathrm{D}$ & C & I \\
\hline Italy & I & $\mathrm{D}$ & $\mathrm{C}$ & $\mathrm{D}$ & I & $\mathrm{D}$ & $\mathrm{C}$ & I & I & $\mathrm{D}$ & I & I \\
\hline Netherlands & $\mathrm{D}$ & $\mathrm{D}$ & $\mathrm{D}$ & I & $\mathrm{D}$ & D & I & I & I & $\mathrm{D}$ & $\mathrm{C}$ & I \\
\hline Portugal & $\mathrm{C}$ & $\mathrm{D}$ & $C$ & $\mathrm{D}$ & $C$ & $\mathrm{D}$ & $\mathrm{C}$ & I & $\mathrm{C}$ & I & $\mathrm{C}$ & I \\
\hline \multirow[t]{2}{*}{ Spain } & $\mathrm{D}$ & $\mathrm{D}$ & I & $\mathrm{D}$ & $\mathrm{D}$ & D & C & I & $\mathrm{D}$ & $\mathrm{D}$ & I & I \\
\hline & \multicolumn{4}{|c|}{ Global to NFC } & \multicolumn{4}{|c|}{ Domestic Banks to NFC } & \multicolumn{4}{|c|}{ NFC to Domestic Banks } \\
\hline Austria & I & C & I & $C$ & C & $\mathrm{D}$ & $\mathrm{D}$ & I & $C$ & $\mathrm{D}$ & I & $\mathrm{D}$ \\
\hline Belgium & I & $\mathrm{D}$ & I & $\mathrm{C}$ & D & $\mathrm{D}$ & $\mathrm{D}$ & $\mathrm{C}$ & $\mathrm{D}$ & $\mathrm{D}$ & $\mathrm{D}$ & I \\
\hline Finland & I & $\mathrm{D}$ & $\mathrm{D}$ & $\mathrm{D}$ & I & $\mathrm{D}$ & I & $\mathrm{C}$ & I & $\mathrm{D}$ & $\mathrm{C}$ & I \\
\hline France & $\mathrm{D}$ & $\mathrm{D}$ & $\mathrm{D}$ & I & $\mathrm{D}$ & $\mathrm{D}$ & $\mathrm{D}$ & $\mathrm{C}$ & $\mathrm{D}$ & $\mathrm{D}$ & $\mathrm{C}$ & $\mathrm{C}$ \\
\hline Germany & $\mathrm{D}$ & $\mathrm{D}$ & $\mathrm{D}$ & $\mathrm{C}$ & $\mathrm{D}$ & $\mathrm{D}$ & $\mathrm{D}$ & I & $\mathrm{D}$ & $\mathrm{D}$ & I & $\mathrm{D}$ \\
\hline Greece & $\mathrm{C}$ & $\mathrm{D}$ & $\mathrm{D}$ & $\mathrm{C}$ & $\mathrm{D}$ & $\mathrm{D}$ & $\mathrm{D}$ & $\mathrm{C}$ & $\mathrm{D}$ & $\mathrm{D}$ & $\mathrm{C}$ & $\mathrm{D}$ \\
\hline Ireland & I & $\mathrm{D}$ & I & $\mathrm{C}$ & $\mathrm{D}$ & $\mathrm{D}$ & $\mathrm{D}$ & $\mathrm{C}$ & $\mathrm{D}$ & $\mathrm{D}$ & I & I \\
\hline Italy & I & $\mathrm{D}$ & $\mathrm{D}$ & $\mathrm{D}$ & $\mathrm{C}$ & $\mathrm{D}$ & $\mathrm{D}$ & $\mathrm{C}$ & $\mathrm{C}$ & $\mathrm{D}$ & $\mathrm{C}$ & $\mathrm{D}$ \\
\hline Netherlands & I & $\mathrm{D}$ & I & $\mathrm{C}$ & $\mathrm{D}$ & $\mathrm{D}$ & $\mathrm{D}$ & I & $\mathrm{D}$ & $\mathrm{D}$ & $\mathrm{D}$ & I \\
\hline Portugal & $\mathrm{C}$ & I & I & $\mathrm{D}$ & I & $\mathrm{D}$ & $\mathrm{D}$ & $\mathrm{C}$ & I & $\mathrm{D}$ & $\mathrm{C}$ & $\mathrm{C}$ \\
\hline Spain & $\mathrm{D}$ & $\mathrm{D}$ & I & $\mathrm{D}$ & D & $\mathrm{D}$ & $\mathrm{D}$ & $\mathrm{D}$ & $\mathrm{D}$ & $\mathrm{D}$ & $\mathrm{C}$ & $\mathrm{C}$ \\
\hline
\end{tabular}

Notes: This Table reports the results from the existing correlation-based tests. FRN and FRC refer to the uncorrected and corrected Forbes-Rigobon (2002) test, DFGM is the regression-based test of Dungey et al. (2005), and DR refers to the test of Dungey and Renault (2018). 'C', 'I' and 'D' represent 'contagion', 'interdependence' and 'de-coupling', respectively.

modes, and relatively low probability of transitioning between these states. The calm regime is the more persistent and has, on average across countries, a less than $6 \%$ chance of transiting to the crisis regime. 'Frequency' measures the proportion of the time that the system spends in the 'crisis' regime. It varies substantially across countries, with Greece being in this high-volatility state for over half the sample (53\%). Portugal also suffers a prolonged crisis with the turbulent regime prevailing for almost $45 \%$ of the sample. Next, there is a club of countries who spend roughly one-third $(30 \%-36 \%)$ of the time in a crisis state, and this includes Belgium, Ireland, Italy, the Netherlands and Spain. At the other extreme, the country for which the crisis is least common is Germany, with less than $20 \%$ of the time spent in the high-volatility regime. 'Duration' captures the persistence of the high-volatility shock. On average, across countries, a high-volatility shock persists for nearly 9 days but ranges from 5 days in the case of Finland to almost 14 days in the model for Greece.

\subsection{Conditional correlations}

Next, we analyze the regime-specific correlations, generated by the MS-FAVAR, for each pair of variables. Although not a statistical test for the stability of relationships, they provide an overview of the comovement changes between regimes. Table 3 presents the correlations.

Firstly, we focus on the relationship between the global banking factor and returns on the domestic banking sector. We observe great heterogeneity across countries, with six (five) countries exhibiting increased (decreased) comovement. Interestingly, countries whose domestic banks suffered large declines, such as Ireland, Spain, and the Netherlands, appear to become more idiosyncratic during the crisis. The largest change is recorded for the Netherlands and appears to be driven by a large downward jump in the banking index, coinciding with the Dutch government bailout of ING in October 2008. While Greece exhibits an increase in correlation in the crisis regime, it is noteworthy that it is much less correlated with the global factor than any of its Eurozone partners in both states.

The change in correlation between the global banking factor and domestic NFCs shows similar dispersion and heterogeneity. No clear pattern emerges, but results suggest that for most countries domestic NFCs decouple from the global banking industry.

Finally, we turn to the regime-specific comovements of the domestic banking and NFC sectors. Here a much clearer pattern emerges, with the vast bulk of countries showing a decline in correlation as we move from 'normal' market conditions to the 'crisis' regime. The relatively lower levels of comovement during the crisis are especially evident for Germany and the Netherlands. This preliminary investigation offers comfort to investors in country portfolios in that it suggests that adverse shocks to a country's banking sector can be diversified away to some degree by holding the stocks of NFCs from that same country.

\subsection{Existing contagion tests}

In Table 4 we present the results of testing for contagion, interdependence and decoupling, using the FRN, FRC, DFGM and DR tests, between the global banking, domestic banking and NFC sectors in each country. In each case the usual mixed evidence for the existence of contagion or otherwise is evident across the different tests. For example, the comparison of results from the FRN and FRC show that the corrected tests always find evidence consistent with reduced shock transmission during the crisis period. That is, where FRN finds contagion (interdependence), FRC tends to find interdependence (decoupling) after adjusting for the volatility changes. This is evident for all types of shocks. Shocks originating in the global banking sector provide mixed evidence across the tests. In the DFGM test these shocks are contagious to domestic banks, but not to the NFC sector, whereas in the DR test this finding is reversed. Both global banking shocks and domestic banking shocks are most frequently contagious to the non-financial sector in the DR test, but show little evidence of this in the DFGM test. 

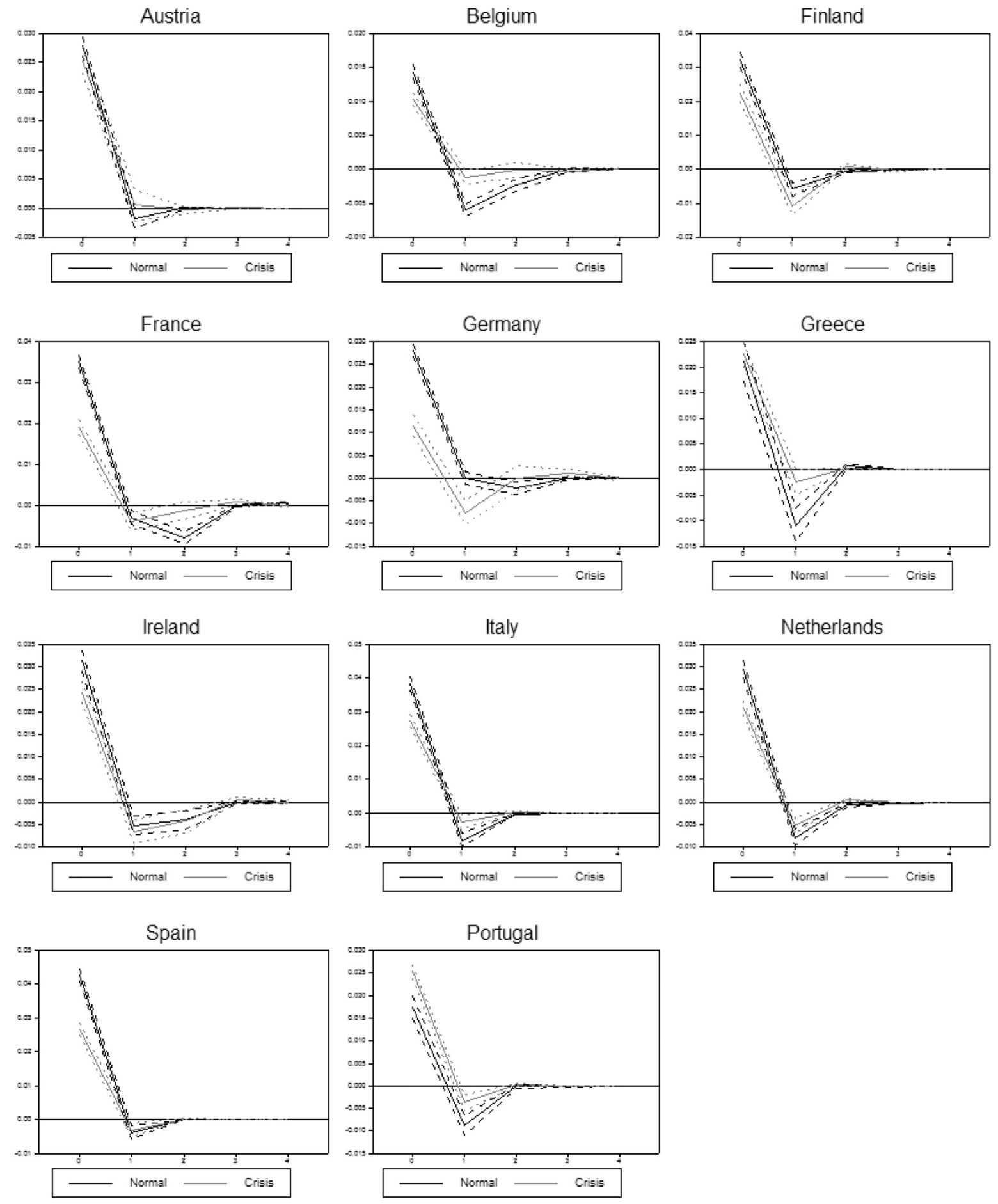

Fig. 1. Response of NFC to Global Bank Shock.

Results are more consistent for the transmission of NFC shocks to the banking sector across countries in that they show little evidence of decoupling. Rather, they are mainly associated with interdependence or contagion effects. In the DR results, the effects are mainly attributed to interdependence, but in the regression approach of DFGM there is more evidence of contagion.

These mixed results are indicative of the state of the contagion literature. There are many tests and understanding how they fit together is critical to interpreting their results as they all tackle slightly different aspects of the problem. The usual result of the FRC detecting less increase (more decrease) in transmission be- tween a normal and crisis period is apparent. The DFGM approach controls for the change in unconditional volatility between normal and crisis periods with stronger statistical properties than the correlation-based tests. It tends to find more evidence of increased transmission than FRC (i.e., more contagion and less decoupling). Finally, the DR test, which controls for the relative change in idiosyncratic variances using conditional variances, provides a view which is between the FRC and DFGM outcomes - with more evidence of contagion and interdependence than FRC but less than DFGM. 

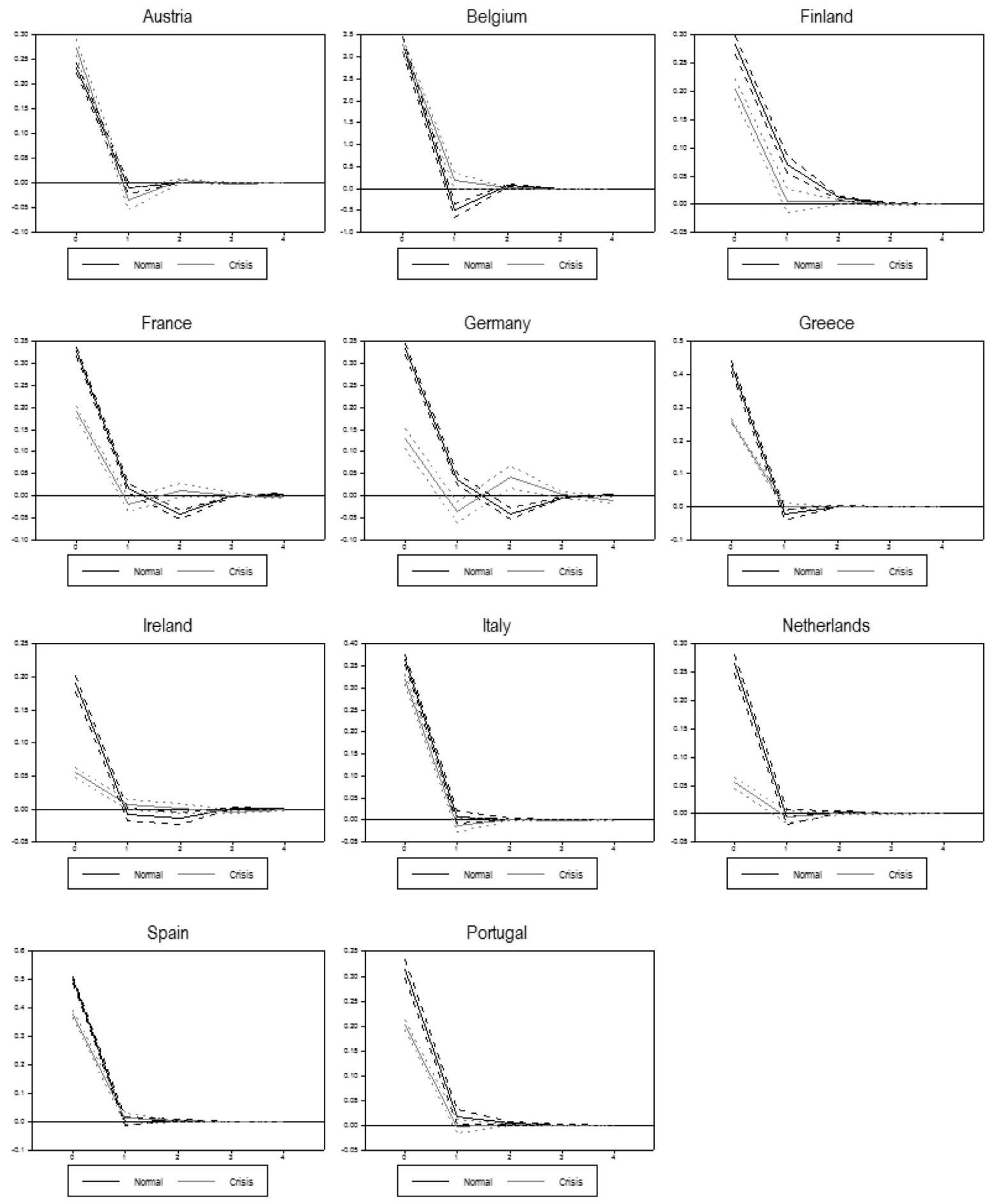

Fig. 2. Response of NFCs to Domestic Bank Shock.

These tests have a number of disadvantages that can be overcome with our MS-FAVAR approach. These include first, that the bivariate tests are not set up to deal with non-contiguous data specifically, so that distortions may arise when using lagged values, particularly in the conditional variance test. Second, the tests are not embedded in the multivariate nature of the model, but rather rely on the extracted shocks. Third, we have to choose an arbitrary threshold to classify the shocks into those associated with calm and crisis - here $p=0.60 .{ }^{14}$ Instead, we progress to the MS-FAVAR approach that produces clearly defined regimes endogenously for each economy and allows us to conduct tests based on the differences between the dynamics of the adjustment process of one sector in response to shocks to another across the two regimes.

\footnotetext{
${ }^{14}$ In practice there is little sensitivity to this choice for our outcomes, however this in itself is perhaps not a recommendation (we tested with $p=0.95, p=0.20$ for robustness).
} 


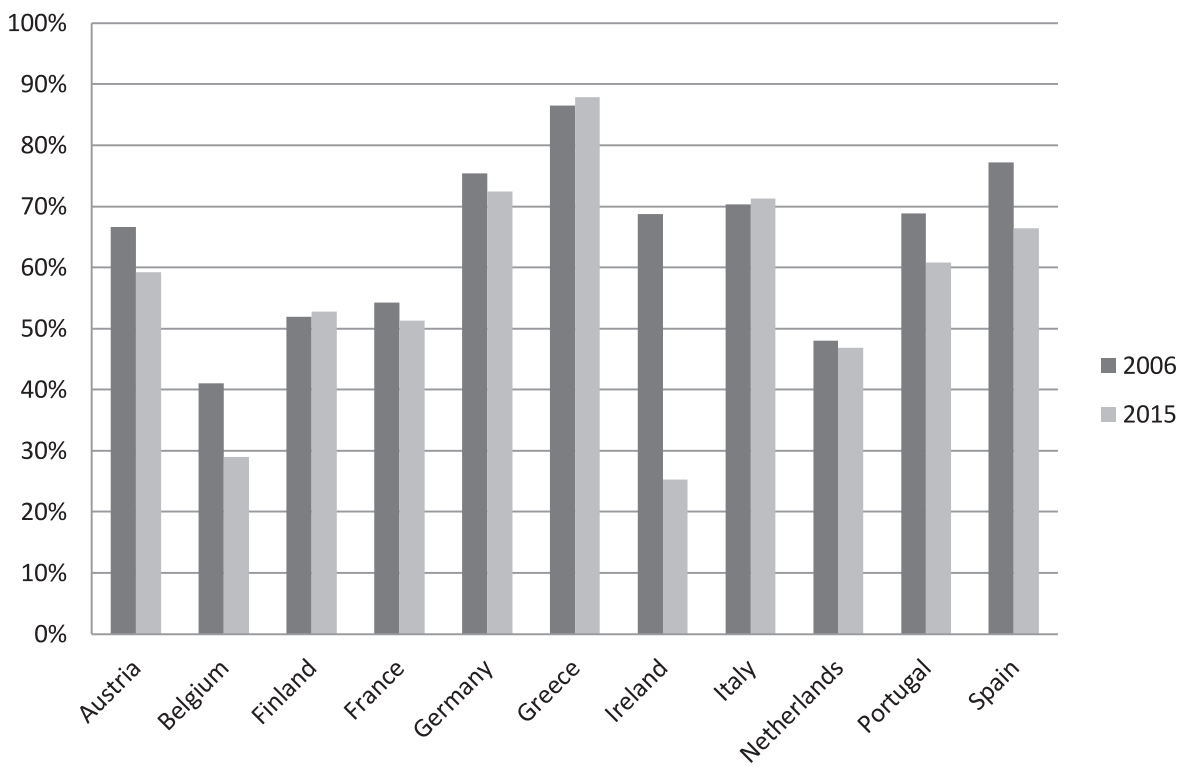

Fig. 3. Ratio of Bank to Total Credit used by Non-Banking Private Firms by country.

Notes: This figure is constructed from the BIS data on Bank sector credit to non-financial private sector (Table F2_4) and Total credit to non-financial private sector (Table F2_2). It shows the ratio of Bank to Total credit from 2 years, 2006 (pre-crisis) and 2015 (end of sample).

Table 5

Summary of contemporaneous responses from GIRFs.

\begin{tabular}{|c|c|c|c|c|c|c|}
\hline & \multicolumn{2}{|l|}{ Global to } & \multicolumn{2}{|c|}{ Domestic banks to } & \multicolumn{2}{|c|}{ Non-financials to } \\
\hline & dom banks & NFCs & global bank & NFCs & global & dom banks \\
\hline Austria & $\mathrm{D}$ & I & C & I & C & $\mathrm{C}$ \\
\hline Belgium & $\mathrm{C}$ & $\mathrm{D}$ & $\mathrm{D}$ & I & $\mathrm{C}$ & I \\
\hline Finland & $\mathrm{C}$ & $\mathrm{D}$ & I & D & I & $\mathrm{C}$ \\
\hline France & I & $\mathrm{D}$ & I & D & I & $\mathrm{C}$ \\
\hline Germany & I & $\mathrm{D}$ & I & D & $\mathrm{D}$ & $\mathrm{D}$ \\
\hline Greece & $\mathrm{C}$ & I & I & D & $\mathrm{C}$ & $\mathrm{C}$ \\
\hline Ireland & C & $\mathrm{D}$ & $\mathrm{D}$ & D & $\mathrm{C}$ & I \\
\hline Italy & I & $\mathrm{D}$ & $\mathrm{C}$ & D & $\mathrm{C}$ & $\mathrm{C}$ \\
\hline Netherlands & $\mathrm{D}$ & $\mathrm{D}$ & $\mathrm{D}$ & D & $\mathrm{C}$ & $\mathrm{D}$ \\
\hline Portugal & $\mathrm{C}$ & C & I & D & $\mathrm{C}$ & $\mathrm{C}$ \\
\hline Spain & $\mathrm{D}$ & $\mathrm{D}$ & I & D & $\mathrm{C}$ & $\mathrm{C}$ \\
\hline
\end{tabular}

Notes: This Table summarises the information from the regime-dependent GIRFs for the transmission of shocks. 'C', 'I' and 'D' represent 'contagion', 'interdependence' and 'decoupling', respectively.

\subsection{Impulse response functions}

To test the hypothesis outlined in Section 2, we generate regime-dependent GIRFs for each of the estimated models and analyze the stability of market linkages between the two regimes. The figures that follow contain the GIRFs, with 95\% confidence bands, of the response of a given market to a shock in another, in both the crisis and non-crisis periods for each country. Table 5 presents a summary of whether the contemporaneous response from one shock type to another represents evidence of contagion, interdependence or decoupling based on the comparison of the point estimates with $95 \%$ confidence bands.

\subsubsection{NFC response to banking shocks}

Figs. 1 and 2 show the responses of the NFC sector to global and domestic banking shocks respectively. In both cases and across all countries, the NFC response to a banking shock is positive (same direction) in the 'normal' regime and, in both regimes, the NFC sectors are more sensitive to domestic as opposed to external banking disturbances. For example, in the normal regime the contemporaneous reaction of the domestic NFC sector to a global banking shock results in a spillover of about $3 \%$ on average across countries, whereas the equivalent number for a domestic banking shock is about $27 \%$. This suggests that NFCs rely more on domestic banks for intermediated loans and it may be that the global shocks, only indirectly affect domestic NFCs through their impact on the domestic banking sector.

Strikingly, during periods of stress, there is little evidence of contagion from the banking shocks to the NFC sector. Their impact on the NFC sector is usually better described as interdependence or decoupling. In fact, decoupling is the predominant outcome in the transmission of both global and domestic banking stocks, suggesting that there is reduced sensitivity to banking shocks among Eurozone NFCs. This finding is consistent with Laeven and Valencia (2013b), Bekaert et al. (2014) and Dungey et al. (2018) who attribute this partly to the success of government interventions in 'disconnecting' banks from the real economy during the crisis.

Blatt et al. (2015) show that changes to market linkages may not always be immediate following a shock and show that changes to the dynamics of relationships can often occur without a contemporaneous effect. Our methodology allows us to detect these types of changes. In this application, shocks tend to die out quickly and there is little change in the dynamics. However, for the case of the transmission of domestic shocks to NFCs (Fig. 2), we find less per- 

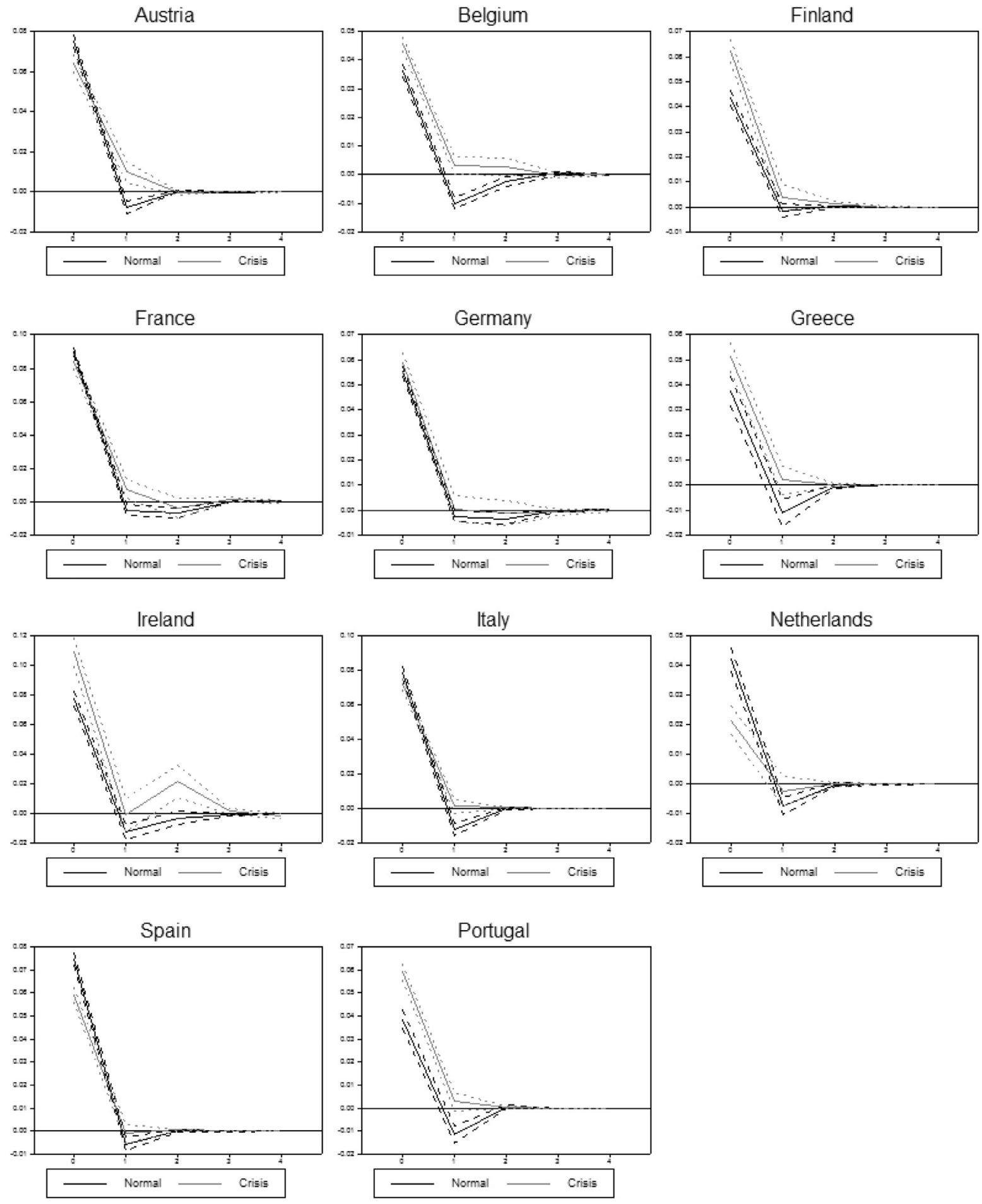

Fig. 4. Response of Domestic Banks to Global Bank Shock.

sistence in Finland, Italy and Portugal to reinforce the contemporaneous decoupling result, while only for Belgium is there evidence of the weaker linkage being offset by greater persistence. The relationship dynamics are unchanged in all other countries.

Our decoupling results indicate that Eurozone NFCs were able to overcome credit flow restrictions during the banking crisis. This is consistent with U.S. studies that show that NFCs were able to replace bank loans by sourcing direct financing on bond markets (e.g. Adrian et al., 2012; and Becker and Ivashina, 2014). Pre-crisis, European corporate bond markets were not very well developed, e.g. Ciccarelli et al. (2015) estimate that about $70 \%$ of the external funding of European firms comes from banks (versus about $20 \%$ in the U.S.). However, Kaya and Wang (2016) and Deutsche Bank (2013) both document a deepening of European bond markets and increased bond issuance by European firms during the crisis.

We use BIS data to look for changes in the composition of NFC debt across our sampled countries. In particular, we analyse the total credit used by non-banking private sector firms and the proportion of it sourced from banks. For all countries, except Finland, to- 


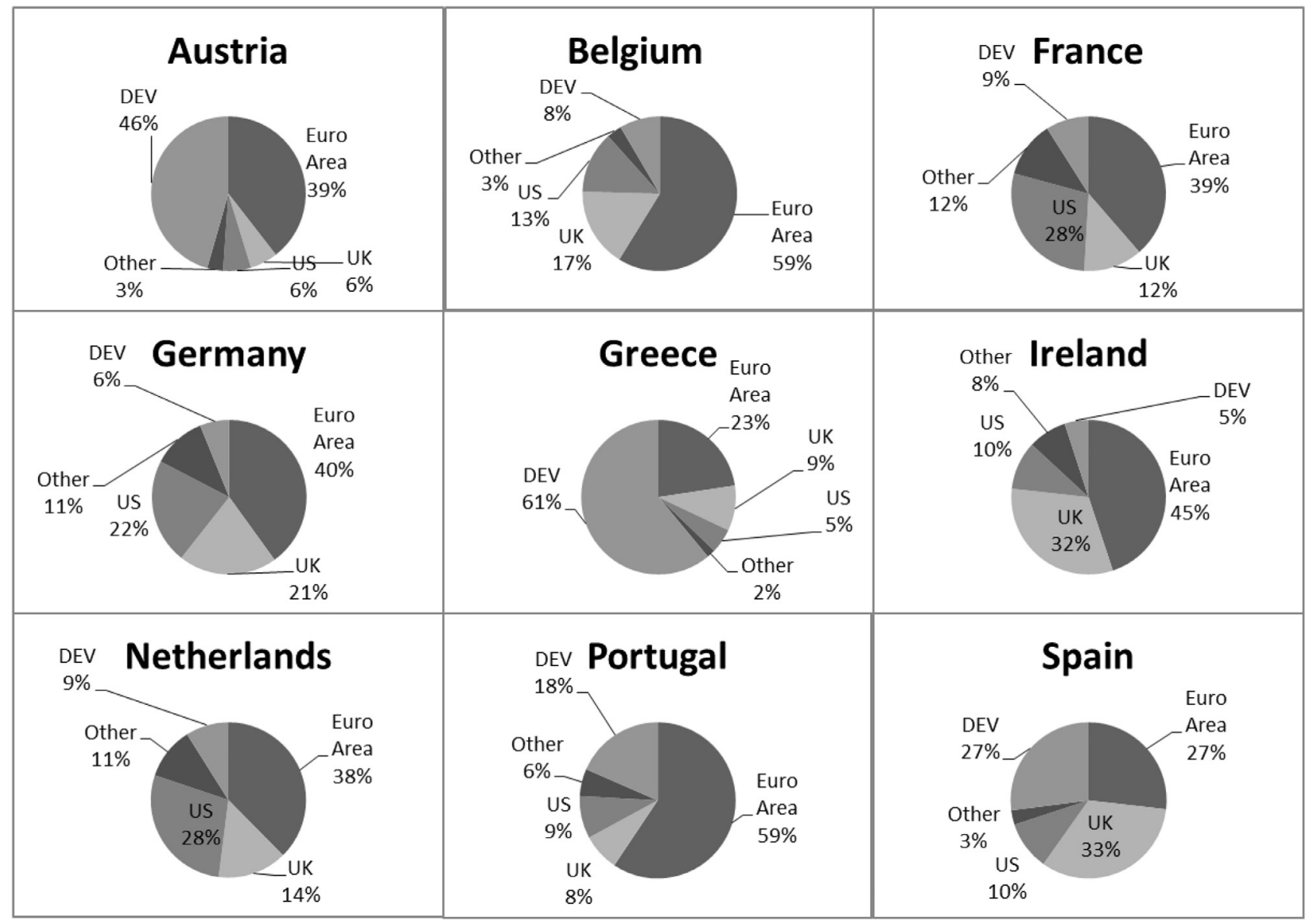

Fig. 5. Regional Breakdown of Foreign Claims as at 31.12.2006.

tal credit employed in the NFC sector has declined and, in general, bank debt has dropped more quickly. Fig. 3 presents a summary, comparing the proportion of NFC debt sourced from banks in the pre-crisis year of $2006^{15}$ with that in the final year of our sample, 2015. For most countries, the ratio of bank to total credit declines, spectacularly in the case of Ireland with a fall of 43 percentage points. Double-digit reductions are also recorded in Belgium and Spain (12 and 11 percentage points respectively). Only two countries - Greece and Italy - show modest increases of 1 percentage point each. For both countries, total private sector credit (and the bank to total credit) peaked later in the sample. Therefore, the success of firms in sourcing alternative direct sources of debt to replace the restricted credit from the banking industry, appears to have been a key factor in the decoupling of the NFC sectors from the global and domestic banks.

Our results are remarkably robust across countries given the large differences in industrial composition of the non-financial sectors across Eurozone stock markets. Therefore diversifying a country portfolio between these two sectors will help offset some of the banking risk through the observed de-coupling of sectors. NFC stocks prove to have better diversification benefits than might have been anticipated from pre-crisis linkages. Of course, all our NFCs are relatively large, exchange-listed firms and it may have been smaller, private firms that bore the brunt of the banking credit

${ }^{15}$ We use 2006 to be consistent with our earlier choice of pre-crisis year but, in fact, total private sector credit in most Euro zone countries did not peak until around 2008 or 2009. contraction, ${ }^{16}$ but notwithstanding, the decoupling result shows that some of the banking shocks (global and domestic) may have been hedged by holding domestic NFC stocks.

\subsubsection{Transmission of shocks within the banking industry}

Fig. 4 shows the response of the domestic banking sector to a global banking shock. During 'normal' market conditions, the domestic banking sectors of all countries react positively, i.e. in the same direction, to a global banking shock. However, the response is relatively muted and ranges from 0.04 to 0.08 . As we move to a 'crisis' episode, the shock transmission for largest banking sectors of Italy, Germany and France remains unchanged (i.e. interdependence). Portugal, Ireland, Greece, Finland and Belgium, all of which had significant problems in their banking sector over this period, experienced contagion whereby shocks in the global banking sector were more strongly felt in the domestic banking sectors for these markets. This is particularly strong in Ireland (an increase of 3 percentage points), with the Irish banking sector being more sensitive to world banking conditions than the other countries. This is consistent with the fact that the growth of Irish banks was fueled by an increasing reliance on interbank markets for funds over the period (Connor et al., 2012). Finally, the banking sectors of Austria, the Netherlands and Spain become less sensitive to, and thus tend to decouple from, global events during the crisis. The scale of the changes in the decoupling case is relatively small - declines of

\footnotetext{
${ }^{16}$ Both Casey and O'Toole (2014) and Carbó-Valverde et al. (2016) show that smaller firms relied more on trade credit than direct loans to offset the effects of credit rationing.
} 

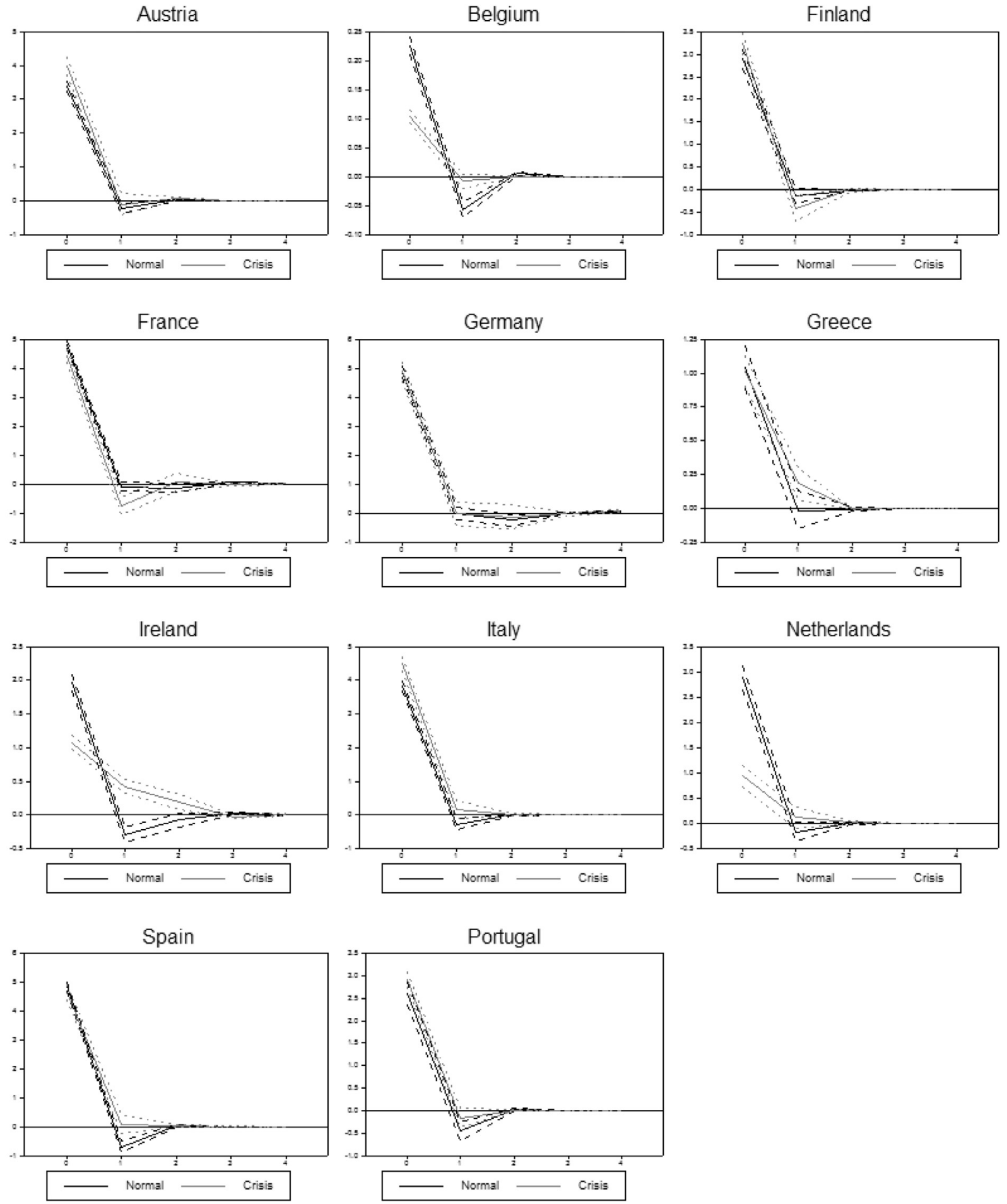

Fig. 6. Response of Global Banking Sector to Domestic Bank Shock.

1.2, 2.2 and 1.8 percentage points respectively - so that they are economically small, but statistically significant. Our results confirm the existence of the international transmission of banking contagion as reported in Dungey and Gajurel (2015). In both studies, France and Italy exhibit interdependence to common shocks, while both Spain and the Netherlands become less responsive during a crisis period.

The dynamics of the relationship change between normal and crisis conditions for many countries. Contagion effects are compounded by increased shock persistence in Belgium, Greece and
Portugal. Though showing no immediate change between regimes, France and Italy also exhibit increased persistence during the crisis, while for Austria, the benefits of decoupling are partially offset by increased persistence of the shock. In summary, only Germany (interdependence), Spain and the Netherlands (decoupling) avoid unanticipated negative repercussions from the global factor during a crisis.

To shed more light on the decoupling result, we analyse the pre-crisis non-domestic assets of the banks across our sampled 

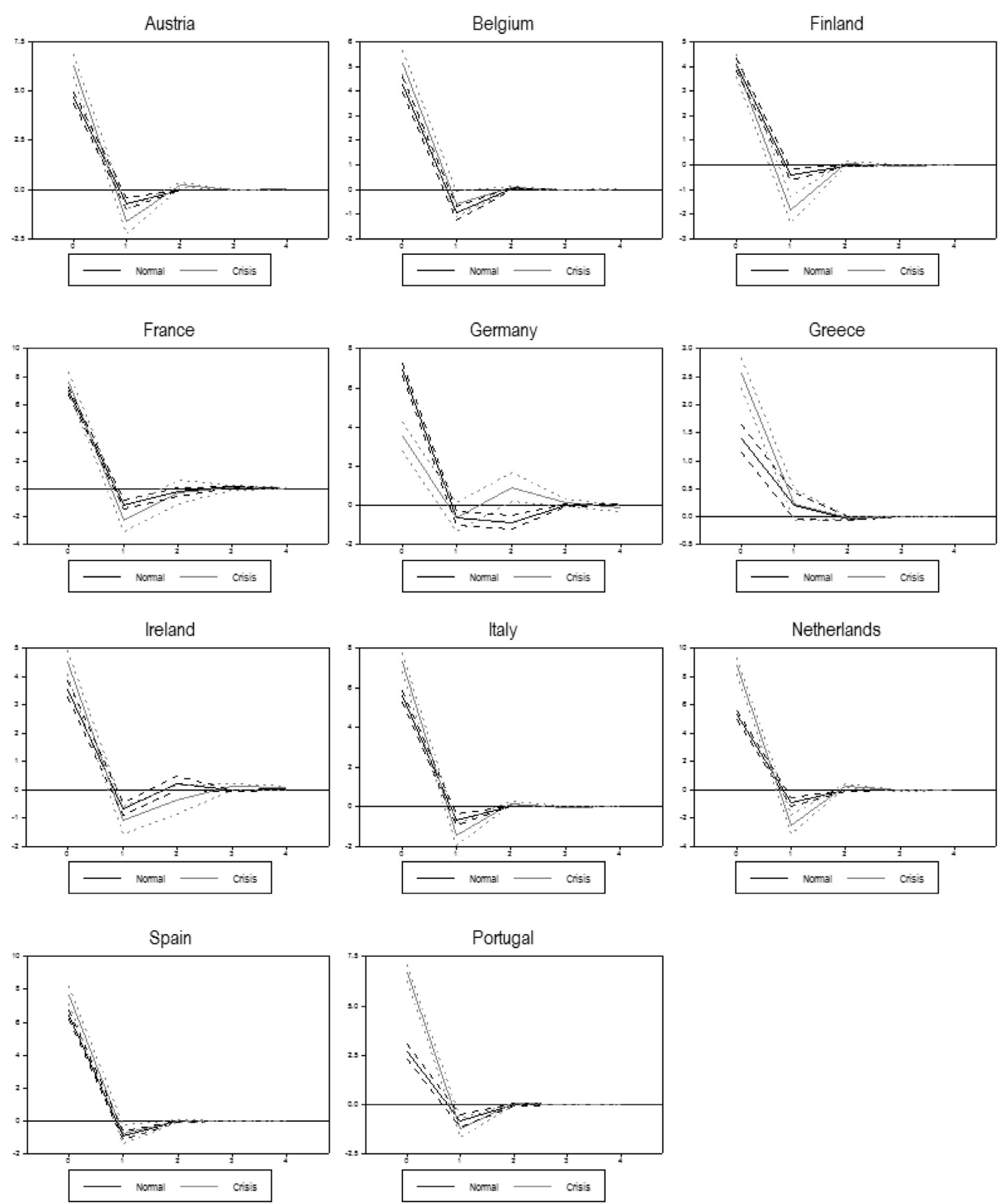

Fig. 7. Response of Global Banking Sector to NFC Shock.

countries. ${ }^{17}$ Fig. 5 presents regional breakdowns of the foreign claims for the domestic banks of each country at the end of December $2006,{ }^{18}$ before a banking crisis began to emerge in any country. In countries where the domestic sector decoupled from the global banking shock - Spain, Netherlands and Austria - we

\footnotetext{
${ }^{17}$ Ideally, we would like to also have the domestic exposures but this data is not available pre-crisis. The BIS and ECB have begun to report this data starting in 2013 Q4.

18 There is no pre-crisis data available for Italy and Finland so we present results for the other nine countries.
}

note that they had a significant exposure to developing markets. For example, Spain had the largest absolute exposure and accounted for $21 \%$ of the claims from this set of Euro zone countries, while Austria and the Netherlands account for $15 \%$ each. A deeper analysis reveals that the Spanish exposure was mainly to the better performing countries of Latin America and the Caribbean; Austria to Emerging Europe; while Dutch banks' developing-country exposure was well diversified across three regions, Latin American and the Caribbean, Asia and Pacific, and Europe. Furthermore, Dutch banks were the only group to have a significant exposure to 

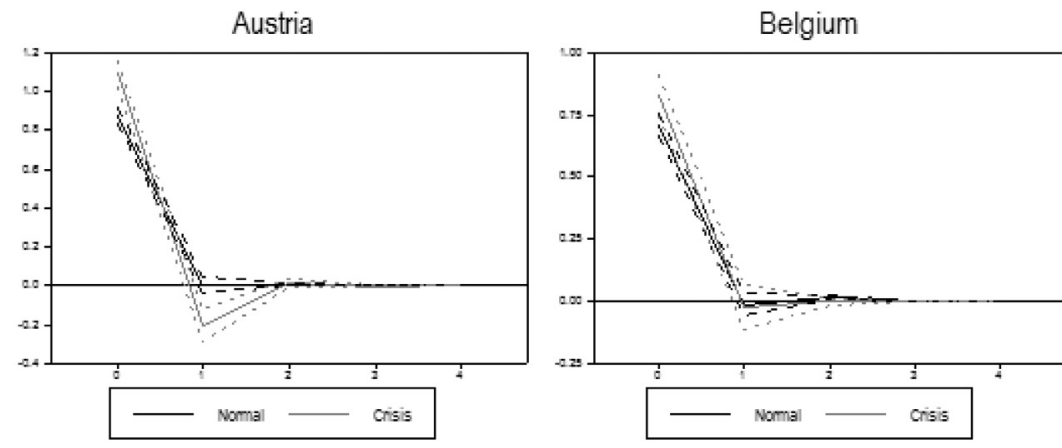

France

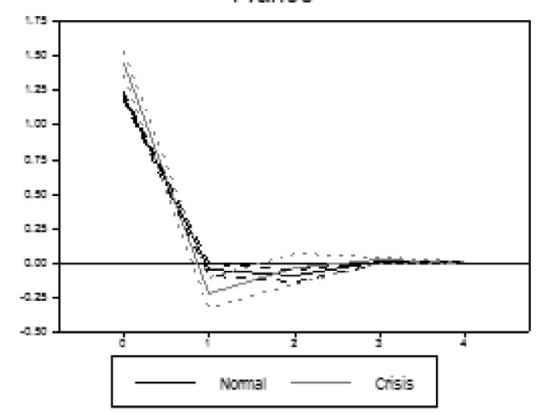

Ireland

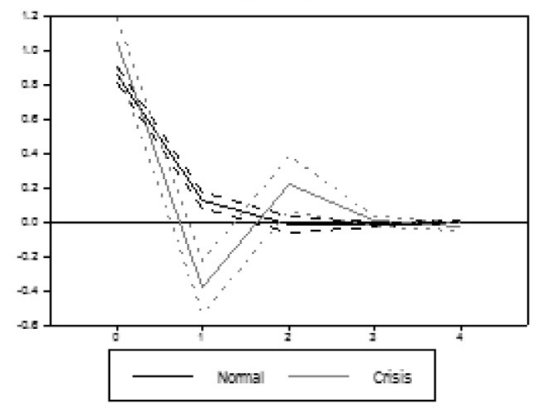

Spain
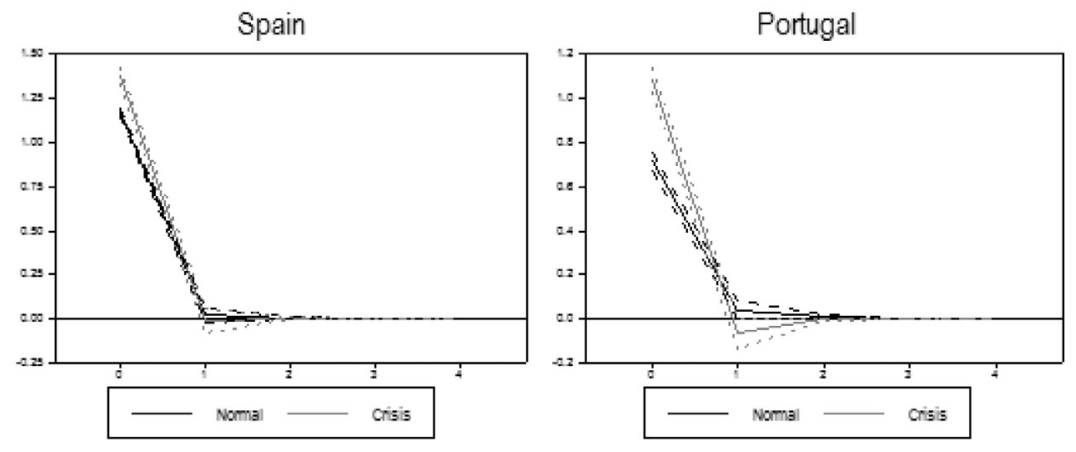

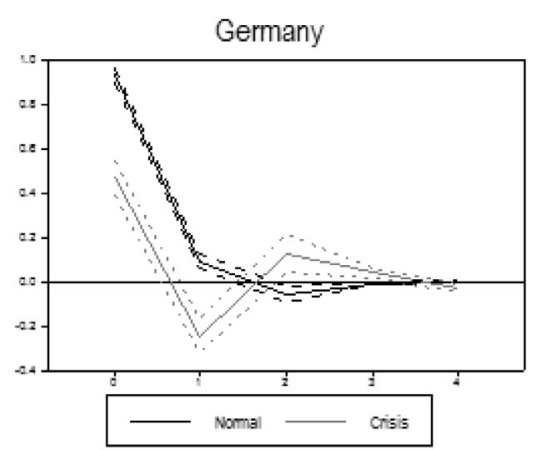

Italy

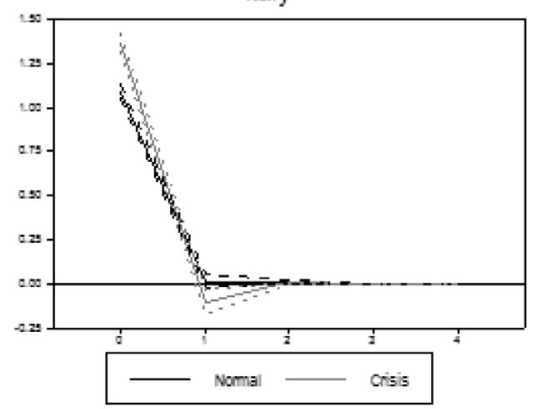

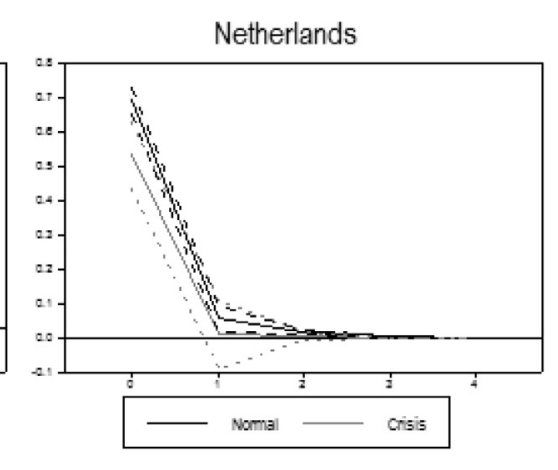

Finland
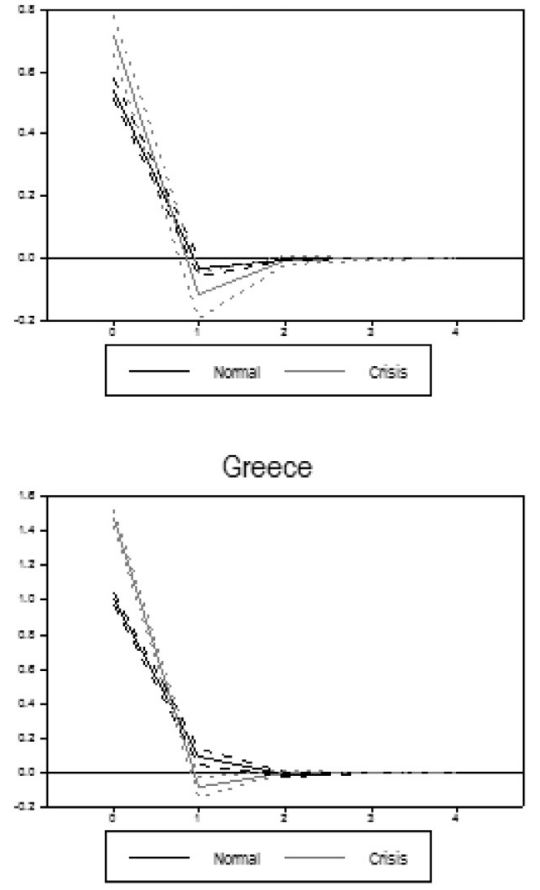

Fig. 8. Response of Domestic Banks to NFC Shock.

Australia and Canada (two developed countries which evaded the worst of the banking crisis), accounting for a further $5 \%$ of their foreign claims. Therefore, the decoupling of these markets from the global factor may be explained, at least in part, by their revenues generated from assets in developing countries that continued to perform well during the global financial crisis.

All remaining countries have concentrated their developing portfolios in Europe and even though it accounts for a large proportion of Greek and Portuguese foreign claims, the absolute size of their foreign positions is small, accounting for only $3 \%$ and $2 \%$ of the total Euro zone exposures to developing countries respec- tively. It is also likely that the magnitude of their domestic problems swamped the benefits accruing from this form of diversification.

Fig. 6 captures the feedback effects of domestic banking shocks to the global banking sector. While there is evidence of contagion feedback to the global banking sector from Austria and Italy, for the majority of the countries domestically sourced banking shocks elicit the same global banking sector response in normal and crisis periods, i.e. there is only evidence of interdependence. The exceptions are for Ireland, the Netherlands and Belgium where decoupling occurs, though the effect for Ireland and Belgium is partially 
undone by greater, but short-lived, persistence. This may reflect that the policy adjustments undertaken in these three markets by their domestic governments to recapitalize their banking sector were the most concerted of those for the countries examined. Other countries where banking crises were domestically important, such as Greece, Spain and Portugal, relied to a much greater extent on programs facilitated by the European Central Bank and the IMF.

\subsubsection{The response of the banking industry to NFC shocks}

Figs. 7 and 8 present the GIRFs for the global and domestic banking response respectively to a shock sourced in the NFC sector. There is strong evidence that, in many countries, these shocks feedback to both the domestic and global banking sectors as contagion. It appears that any negative shocks suffered by NFCs further exacerbated the already stressed position of the banking industry during the crisis period. This is consistent with the models of Acemoglu et al. (2015) and Kiyotaki and Moore (1997) in which shocks in the NFC sector cause problems for the banking sector via a robust-but-fragile effect apparent during periods of stress. NFC shocks in Greece, Italy, Ireland, Portugal and Spain all result in contagion to both their domestic and global banking sectors. These are the so-called GIIPS countries at the heart of the 2010-12 European crisis. The Netherlands and Austria also generated contagion from NFC shocks to the global banking sector. With the exception of Germany, which acted as a safe haven market during this crisis, interdependence characterizes the transmission of NFC shocks to the global banking sector during the crisis period in each of the other markets. The decoupling of German markets from other European markets is also apparent in Dungey and Renault (2018). The dynamics of the responses are largely unaffected by the transition to a crisis regime, though both Finland and the Netherlands show a quicker reversal of the shock.

The evidence of changing transmission between NFC shocks and the domestic banking sector differs for Finland, Ireland and the Netherlands from the effects of these shocks on global banking sector. In Finland, NFC shocks are contagious to the domestic banking sector. Finland weathered the events of 2008-2010 relatively well, but has since faced considerable domestic problems due to falling exports and rising labour costs. While the financial sector in Finland is well regulated and adequate credit is available (OECD Economic Surveys: Finland 2014), the majority of wholesale funds are sourced from other Nordic markets so that the domestic sector alone is relatively small. Consequently, the contagion effects of the NFC shocks represent the impact of the reduction in competitiveness in the Finnish economy on those banks, which are located in the Finnish domestic banking sector according to the Datastream index selection conditions. In Ireland and the Netherlands, the propagation of NFC shocks to the domestic banking sector remains unchanged between the calm and crisis periods in terms of the initial impact. In addition, Ireland exhibits a stronger reversal of the initial shock in the crisis regime. This may be attributable to the policy actions of these two countries, where actions were taken rapidly to address the re-capitalization of the banking sector, improve banking supervision and foster a market perception of credible movement towards macroeconomic sustainability.

\section{Robustness checks}

We check the robustness of our results by estimating a range of alternatively specified models. Firstly, we investigate the impact of adding an extra variable to our MS-FAVAR model. ${ }^{19}$ We include the second principal component as an extra regressor and,

${ }_{19}$ All of the results of these robustness checks are available in a set of (unpublished) ancillary results to the paper. This document is available at [to be inserted]. in a separate specification, we include a pure U.S. factor. The latter results from orthogonalizing the U.S. bank sector return with respect to the first principal component. In both specifications, the results of Table 5 regarding contagion, interdependence and decoupling prove to be robust in the vast majority of cases. Contagion is limited to within the banking industry and there is widespread evidence of decoupling of domestic NFCs from both global and domestic banks. There are some changes to the dynamics (mainly due to different lag lengths being selected) but these have a relatively small impact and quickly die out of the system.

Secondly, we deal with the fact that our global banking factor is a generated variable and may cause some biases in the estimation. We follow Connor and Korajczyk (1986) who show that as the number of cross-sectional units grows, the extracted factor becomes a consistent estimator of the true factor. Thus, we repeat our analysis with the number of country banking sector returns extended to $50^{20}$ (13 in the earlier results). We use the first principal component from this exercise as our global banking factor and proceed as before. Again, a robust picture emerges from the analysis and our conclusions are unchanged regarding the incidences of contagion, interdependence and decoupling. Again, there are some changes to the dynamics but shocks have little persistence.

\section{Conclusions}

We assess the impact of shocks transmitted between the global banking sector, domestic banking sector and the non-financial sector for eleven Eurozone countries over the period 2004-2015. Using an MS-FAVAR model we endogenize the identification of periods of normality and crisis in each market and use these to test whether the transmission of shocks between the global banking, domestic banking and non-financial sectors is altered between normal and crisis periods. That is, we test whether transmission is unchanged, increased or decreased, consistent with integration, contagion and decoupling effects in the markets.

We find that while global banking shocks generate contagious effects for the domestic banking sectors for a substantial number of countries but there are relatively few instances when domestic banking shocks generate contagion for the global market. In general, the transmission of shocks from domestic banks to the global banking sector is unchanged between normal and crisis times, consistent with interdependence (and even provides evidence of decoupling for Ireland, the Netherlands and Belgium).

We found little evidence of contagion from banking shocks to the non-financial sector. In most cases, NFCs managed to decouple from both global and domestic banks during the financial turmoil. Even though, NFCs are far more sensitive to domestic bank shocks in both regimes, they still succeeded in lowering their responses during the crisis by about $38 \%$ on average across all countries. One could argue that this was due to the policies implemented during the crisis, and though they may have helped to cushion the shock, it is unlikely to be the whole story. This result is broadly similar across all Eurozone countries, even though the extent (and types) of government support for their domestic banking sectors varied widely (see Laeven and Valencia, 2013a). It seems that nonfinancial firms were able to access alternative funding sources and substitute bank loans with direct loans on the corporate bond markets. Corporate bond markets continued to function and supply funds to creditworthy NFCs. This is encouraging for the adoption of policies that strive to develop such bond markets within the EU. Efforts to keep credit flowing in the domestic economies during crises may benefit from policies aimed at deepening and development of corporate bond markets and / or reducing barriers for NFC

\footnotetext{
20 We include all countries for which Datastream has data on their banking sectors over our sample period of January 1, 2004 to March 31, 2015.
} 
firms in accessing these markets, e.g. reducing costs of attaining a credit rating by either direct support or tax write-offs. ${ }^{21}$

Finally, we find strong evidence that non-financial sector shocks propagate contagion to the domestic and global banking sectors during the crisis periods. The transmission of non-financial sector shocks to the banking sectors is statistically larger during the crisis period than the normal period. For GIIPS countries this effect is pronounced for contagion from the non-financial sector to global banking markets, but the results for the transmission to domestic banking sectors is more mixed.

Banks with better diversified asset bases fared better during the crisis as they were able to decouple from global banking conditions. Larger exposure to emerging markets enabled the banks of Austria, Spain and the Netherlands to offset some of the global turmoil. Greater disclosure of banks' aggregate asset exposures by geographical area and distinction between non-financial and financial sectors should be encouraged so that investors and regulators can better assess their vulnerability to shocks.

\section{Acknowledgments}

We thank two anonymous referees, Bertrand Candelon, Maurizio Michael Habib and other participants at the New Financial Reality seminar in the IPAG Business School (Nice, 2015), International Finance and Banking Society conference (Barcelona, 2016), and the Irish Economic Association conference 2016 for their comments on earlier drafts of this paper.

\section{References}

Acemoglu, D., Ozdaglar, A., Tahbaz-Salehi, A., 2015. Systemic risk and stability in financial networks. Am. Econ. Rev. 105 (2), 564-608.

Adrian, T., Colla, P., Shin, H.S., 2012. Which financial frictions? Parsing the evidence from the financial crisis of 2007-09. NBER working paper 18335. Cambridge, MA.

Allen, F., Babus, A., Carletti, E., 2012. Asset commonality, debt maturity and system risk. J. Financ. Econ. 104 (3), 519-534.

Allen, F., Gale, D., 2000. Financial contagion. J. Political Econ. 108 (1), 1-33.

Bae, K.H., Karolyi, A., Stulz, R.M., 2003. A new approach to measuring financial contagion. Rev. Financ. Stud. 16 (3), 717-763.

Becker, B., Ivashina, V., 2014. Cyclicality of credit supply: firm level evidence. J. Monetary Econ. 62, 76-93.

Bekaert, G., Ehrmann, M., Fratzscher, M., Mehl, A., 2014. The global crisis and equity market contagion. J. Financ. 69 (6), 2597-2649.

Bekaert, G., Hodrick, R.J., Zhang, X., 2009. International stock return comovements J. Financ. 64 (6), 2591-2626.

Bernanke, B., 1983. Non-monetary effects of the financial crisis in the propagation of the great depression. Am. Econ. Rev. 73 (3), 257-276

Bernanke, B.S., Boivin, J., Eliasz, P., 2005. Measuring the effects of monetary policy: a factor-augmented vector autoregressive (FAVAR) approach. Q. J. Econ. 120 (1), 387-422.

Bernanke, B.S., Gertler, M., 1985. Banking in general equilibrium. NBER working paper 1647. Cambridge, MA.

Bialkowski, J., Serwa, D., 2005. Financial contagion, spillovers and causality in the Markov switching framework. Quant. Financ. 5 (1), 123-131.

Bialkowski, J., Bohl, M., Serwa, D., 2006. Testing for financial spillovers in calm and turbulent periods. Q. Rev. Econ. Financ. 46 (3), 397-412.

Blatt, D., Candelon, B., Manner, H., 2015. Detecting contagion in a multivariate time series system: an application to sovereign bond markets in Europe. J. Bank. Financ. 59, 1-13.

Boyson, N., Stahel, C., Stulz, R., 2010. Hedge fund contagion and liquidity shocks. J. Financ. 65 (5), 1789-1816.

Brei, M., Gambacorta, L., von Peter, G., 2013. Rescue packages and bank lending. J Bank. Financ. 37 (2), 490-505.

Brunnemeier, M., Garciano, L., Lane, P., Pagano, M., Reis, R., Santos, T., Thesmar, D., Van Nieuwerburgh, S., Vayanos, D., 2016. The sovereign-banking diabolical loop and ESBies. Am. Econ. Rev. Pap. Proc. 106 (5), 508-512.

Busetti, F., Harvey, A., 2011. When is a copula constant? A test for changing relationships. J. Financ. Econ. 9 (1), 106-131.

Caporin, M., Pelizzon, L., Ravazzolo, F., Rigobon, R., 2018. Measuring sovereign contagion in Europe. J. Financ. Stab. 34, 150-181.

\footnotetext{
21 Brei et al. (2013) show that many recapitalization programmes only result in increased bank lending to the private sector when their own balance sheets have been restored to health.
}

Carbó-Valverde, S., Rodríguez-Fernández, F., Udell, G, 2016. Trade credit, the financial crisis and firms access to credit. J. Money Credit Bank. 48 (1), 113-143.

Casey, E., O'Toole, C.M., 2014. Bank lending constraints, trade credit and alternative financing during the financial crisis: evidence from European SMEs. J. Corp. Financ. 27, 173-193.

Ciccarelli, M., Maddaloni, A., Peydró, J.L., 2015. Trusting the bankers: a new look at the credit channel of monetary policy. Rev. Econ. Dyn. 18, 979-1002.

Claeys, P., Vasicek, B., 2014. Measuring bilateral spillover and testing contagion on sovereign bond markets in Europe. J. Bank. Financ. 46, 151-165.

Connor, G., Flavin, T., O’Kelly, B., 2012. The U.S. and Irish credit crises: their distinctive differences and common features. J. Int. Money Financ. 31, 60-79.

Connor, G., Korajczyk, R., 1986. Performance measurement with the arbitrage pricing theory: a new framework for analysis. J. Financ. Econ. 15, 373-394.

Contessi, S., De Pace, P., Guidolin, M., 2014. How did the financial crisis alter the correlations of U.S. yield spreads. J. Empir. Financ. 28, 362-385.

Corsetti, G., Pericoli, M., Sbracia, M., 2005. 'Some contagion, some interdependence': more pitfalls in tests of financial contagion. J. Int. Money Financ. 24 (8), 1177-1199.

De Bandt, O., Malik, S., 2010. Is there evidence of shift-contagion in international housing markets? Banque de France working paper no. 295.

Deutsche Bank, 2013. Corporate bond issuance in Europe: Where do we stand and where are we heading? Deutsche Bank Research, Frankfurt am Main, Germany.

Dungey, M., Fry, R., Gonzalez-Hermosillo, B., Martin, V., 2005. Empirical modeling of contagion: a review of methodologies. Quant. Financ. 5 (1), 9-24.

Dungey, M., Gajurel, D., 2015. Contagion and banking crisis - international evidence for 2007 - 09. J. Bank. Financ. 60, 271-283.

Dungey, M., Luciani, M., Veredas, D., 2018. Systemic risk in the US: interconnectedness as a circuit breaker. Econ. Model. 71, 305-315.

Dungey, M., Milunovich, G., Thorp, S., Yang, M., 2015. Endogenous crisis dating and contagion using smooth transition structural GARCH. J. Bank. Financ. 58, 71-78.

Dungey, M. Renault, E., 2018. Identifying Contagion. J. Appl. Econ. 33 (2), 227-250.

Dwyer, G.P., Devereux, J., Baier, S., Tamura, R., 2013. Recessions, growth and banking crises. J. Int. Money Financ 38, 18-40.

Ehrmann, M., Ellison, M., Valla, N., 2003. Regime-dependent impulse response functions in a Markov-switching vector autogression model. Econ. Lett. 78, 295-299.

Elliot, M., Golub, B., Jackson, M., 2014. Financial networks and contagion. Am. Econ. Rev. 104 (10), 3115-3153.

Favero, C., Giavazzi, F., 2002. Is the international propagation of financial shocks non-linear? Evidence from the ERM. J. Int. Econ. 57, 231-246.

Flavin, T.J., Panopoulou, E, 2009. On the robustness of international portfolio diversification benefits to regime-switching volatility. J. Int. Financ. Mark. Money 19 140-156.

Flavin, T.J, Sheenan, L., 2015. The role of U.S. subprime mortgage-backed assets in propagating the crisis: contagion or interdependence. North Am. J. Econ. Financ. $34,167-186$

Forbes, K.J., Rigobon, R.J., 2002. No contagion, only interdependence: measuring stock market comovements. J. Financ. 57 (5), 2223-2261.

Fry-McKibben, R.A., Hsiao, C.Y., 2015. Extremal Dependence Tests for Contagion. Australian National University CAMA working paper no. 40/2015.

Grammatikos, T., Vermeulen, R., 2012. Transmission of the financial and sovereign debt crises to the EMU: stock prices, CDS spreads and exchange rates. J. Int. Money Financ. 31, 517-533.

Gravelle, T., Kichian, M., Morley, J., 2006. Detecting shift-contagion in currency and bond markets. J. Int. Econ. 68 (2), 409-423.

Gropp, R., Lo Duca, M., Vesala, J., 2009. Cross-border bank contagion in Europe. Int J. Cent. Bank. 5 (1), 97-139.

Jeanne, O., Masson, P., 2000. Currency crises, sunspots and Markov-switching regimes. J. Int. Econ. 50, 327-350.

Kallberg, J., Liu, C., Pasquariello, P., 2005. An examination of the Asian crisis: regime shifts in currency and equity markets. J. Bus. 78 (1), 169-211.

Kaminsky, G., Reinhart, C., Vegh, C., 2003. The unholy trinity of financial contagion. J. Econ. Perspect. 17 (4), 51-74

Kaya, O., Wang L, 2016. The role of bank lending tightening on corporate bond issuance in the Eurozone. Q. Rev. Econ. Financ. 60, 1-11.

Kiyotaki, N., Moore, J., 1997. Credit cycles. J. Political Econ. 105 (2), 211-248.

Konermann, P., Meinerding, C., Sedova, O., 2017. Asset allocation in markets with contagion: the interplay between volatilities, jump intensities and correlations. Rev. Financ. Econ. 22, 36-46.

Korinek, A, Roitman, A, Végh, C.A., 2010. Decoupling and recoupling. Am. Econo. Rev. 100 (2), 393-397.

Laeven, L., Valencia, F., 2013a. Systemic banking crises database. IMF Econ. Rev. 61 (2), 225-270.

Laeven, L., Valencia, F., 2013b. The real effects of financial sector interventions during crises. J. Money Credit Bank. 45 (1), 147-177.

Pasquariello, P., 2008. The anatomy of financial crises: Evidence from the emerging ADR market. J. Int. Econ. 76, 193-207.

Peek, J., Rosengren, E.S., Tootell, G.M.B., 2003. Identifying the macroeconomic effect of loan supply shocks. J. Money Credit Bank. 35 (6), 931-946.

Reinhart, C.M., Rogoff, K.S., 2009. The aftermath of financial crises. Am. Econ. Rev. 99 (2) 466-472

Tong, H., Wei, S-J., (2009). The misfortune of non-financial firms in a financial crisis: disentangling finance and demand shocks. CEPR Discussion paper no. 7208. 